\title{
INTERPRETACIÓN LITERAL: JURISTAS Y LINGÜISTAS FRENTE A FRENTE*
}

\author{
Tecla Mazzarese \\ Universidad de Brescia
}

\begin{abstract}
All that the unsuspecting Bilbo saw that morning was an old man with a staff. [...] «Good morning!» said Bilbo, and he meant it. The sun was shining, and the grass was very green. But Gandalf looked at him from under long bushy eyebrows that stuck out further than the brim of his shady hat.

«What do you mean?» he said. «Do you wish me a good morning whether I want it or not; or that you feel good this morning; or that it is a morning to be good on?» «All of them at once» said Bilbo. «And a very fine morning for a pipe of tobacco out of doors, into the bargain. [...]

«Very pretty» said Gandalf. «But I have no time to blow smoke-rings this morning. I am looking for someone to share in an adventure that I am arranging, and it's very difficult to find anyone.»

«I should think so -in these parts. We are plain quiet folk and have no use for adventures. Nasty disturbing uncomfortable things. Make you late for dinner! [...] He had decided that he was not quite his sort, and wanted him to go away. But the old man did not move. [...]

«Good morning!» he said at last. «We don't want any adventures here, thank you! $[\ldots] »$ By this he meant that the conversation was at an end.

«What a lot of things you do use Good morning for!» said Gandalf. «Now you mean that you want to get rid of me, and that it won't be good till I move off.»

[J.R.R. Tolkien, The Hobbit or There and back Again, 1937.]
\end{abstract}

\section{Introducción}

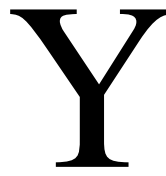

a en 1923, fecha de publicación de The Meaning of Meaning, Ogden y Richards ofrecieron un abanico embarazosamente amplio de las diversas formas de entender la noción de «significado» en la literatura de filosofía del lenguaje.

Las diversas concepciones, distintas en sus asunciones y/o en sus implicaciones de carácter ontológico, filosófico y stricto sensu lingüístico, parecen sin embargo compartir una característica común, aunque sea sólo ex negativo: una escasa atención a, cuando no una clara crítica de, la noción de «significado literal».

* Versión española de Interpretazione letterale: giuristi e linguisti a confronto. En: Velluzzi, Vito (ed.): Significato letterale e interpretazione del diritto, Torino, Giappichelli, 2000, p. 95-136. Este trabajo reproduce, con algunas ligeras modificaciones y/o integraciones, la ponencia: «Literal Interpretation: Jurists and Linguists Confronted», presentada en el IVR 18th World Congress, La Plata / Buenos Aires, agosto 1997. 
Vale la pena subrayar que esta afirmación no está en absoluto circunscrita a una literatura condicionada por perniciosas influencias de carácter deconstruccionista y/o postpositivista. Al contrario, esa afirmación encuentra ya una confirmación (parcial) a finales del siglo XIX en los trabajos de Frege, que son considerados convencionalmente el punto de partida de la moderna filosofía del lenguaje y de la lingüística general ${ }^{1}$.

En manifiesto y sorprendente contraste con esta tendencia generalmente compartida por los lingüistas, los juristas, en cambio, continúan considerando la interpretación literal y, por tanto, la noción subyacente de «significado literal», como el nodo central de la interpretación jurídica. Esta afirmación encuentra su apoyo:

(a) en primer lugar, en la importancia que el legislador (ya sea nacional o internacional) sigue atribuyendo al canon literal al fijar las directivas que deben seguirse en la interpretación y en la aplicación del derecho;

(b) en segundo lugar, en la convicción por parte de los jueces y demás operadores jurídicos de que fundan sus propias actividades (por muy diversas que sean) en una interpretación literal del derecho, en cumplimiento de lo que les es requerido por las directivas interpretativas del legislador;

(c) en tercer lugar, en la importancia que los iusfilósofos siguen atribuyendo a las nociones de significado literal y de interpretación literal (aun conociendo el carácter problemático de ambas). Así es, por ejemplo, cuando definen y/o defienden la noción de «proposición normativa» (esto es, de proposición que tiene por objeto la descripción de una norma); cuando sostienen la función (la naturaleza) descriptiva de la dogmática jurídica; cuando ignoran algunos de los problemas con los que se encuentra la traducción del lenguaje jurídico.

La manifiesta divergencia entre la aproximación de los lingüistas y la de los juristas justifica dos interrogantes:

El primer interrogante es: ¿Qué entienden los juristas por «interpretación literal»y, respectivamente, por «significado literal»?

El segundo interrogante es: ¿Por qué los juristas siguen usando con profusión estas nociones tan amplia y drásticamente criticadas?

No es difícil responder al segundo interrogante.

Aun cuando pueda parecer simple y banal, la respuesta es de naturaleza ideológica. Los juristas continúan haciendo referencia a la interpreta-

${ }^{1}$ Para una identificación de los rasgos comunes y las diferencias específicas entre filosofía del lenguaje, filosofía lingüística y lingüística (general) véase, por ejemplo, D. Marconi [1995, pp. 365-373]. En el análisis que prosigue, «lingüístico» se usa, en un sentido muy general, para hacer referencia a todo lo que concierne al ámbito de la lingüística (general) y/o de la semiótica y/o de la filosofía del lenguaje; «lingüista», en un sentido igualmente general, se usa para hacer referencia a todo aquél que, especializadamente, se ocupe de temáticas lingüísticas. 
ción literal y al significado literal porque estas nociones les permiten defender y (re)afirmar el valor de la seguridad jurídica, ignorando (sino negando) el problema de la discrecionalidad en la aplicación (judicial o no) del derecho.

El primer interrogante, a diferencia del segundo, no admite una respuesta simple y unívoca; al menos por dos razones diversas:

(a) en primer lugar, la falta de uniformidad en el uso de los juristas del término «literal» en las locuciones «interpretación literal» $\mathrm{y}$ «significado literal»;

(b) en segundo lugar, la falta de uniformidad en el uso de los juristas del término «interpretación» en la locución «interpretación literal».

Este trabajo se articula en tres partes principales. La primera parte $(\S 1$.) está dedicada a una sumaria relación de algunas de las críticas y/o reservas principales formuladas por los lingüistas a la noción de «significado literal». La segunda parte ( $(2)$, en cambio, llamará la atención sobre los distintos usos que hacen los juristas del término «literal» en las locuciones «significado literal» e «interpretación literal» (\$ 2.1.) y del término «interpretación» en la locución «interpretación literal» (§ 2.2.). La tercera parte (§ 3.), finalmente, ofrecerá algunos comentarios acerca del carácter ideológicamente comprometido de la decisión de los juristas de defender las dos nociones examinadas.

\section{Las dudas de los lingüistas sobre la noción de «significado literal»}

La duda de si los lingüistas han tomado nunca en serio la noción de «significado literal», aun cuando sea excesivamente radical en su formulación, surge a partir de su difundida tendencia a ignorar o, como máximo, a dar por descontado qué deba entenderse por «significado literal»; en otras palabras, esa duda surge dado el prevaleciente interés de los lingüistas por todo aquello que pueda interferir con el significado literal (así, por ejemplo, fenómenos como la ambigüedad o la vaguedad) y/o por todo aquello que se contraponga al significado literal (como, por ejemplo, el significado metafórico o el significado figurativo), más que por qué pueda entenderse por «significado literal».

Sorprendentemente, esa duda obtiene una confirmación adicional en los argumentos presentes en la literatura de los últimos diez años que ha emprendido la defensa de la noción de significado literal de los ataques más violentos de los que ha sido objeto.

A los efectos de presentar un abanico, aunque sea sumario, de las principales dificultades con las que se enfrenta el intento de ofrecer una definición rigurosa y puntual de la noción en examen, propondré una cuatripartición de las principales posiciones mantenidas por los lingüistas sobre el te- 
ma del significado literal ${ }^{2}$. Más precisamente, siguiendo la propuesta terminológica de Dascal de llamar «literalismo moderado» («moderate literalism») a su defensa de la noción de significado literal ${ }^{3}$, los cuatro apartados en los que articularé esta cuatripartición serán, respectivamente: (a) literalismo; (b) antiliteralismo moderado (latente); (c) antiliteralismo radical (manifiesto); y (d) literalismo moderado.

La reconstrucción que propongo aquí se limita a los trabajos de la moderna filosofía del lenguaje y/o de la lingüística general, disciplinas que tienen como punto de partida convencional los análisis de Frege ${ }^{4}$.

\subsection{Literalismo}

Con la locución «literalismo», denomino la posición favorable de los lingüistas (en el caso de que exista) acerca de la noción de «significado literal»; esto es, la posición que se considera el fundamento de la concepción intuitiva habitual de «significado literal».

No es fácil decir con precisión en qué consiste el literalismo. Como admite, en efecto, el propio Dascal, que es un denodado defensor del mismo,

Few if any authors have given a set of sufficient and necessary conditions for defining literal meaning 5 .

Una excepción, siempre según Dascal, es la que presenta Katz con su «criterio de la carta anónima» 6 :

literal meanings, whatever they are, should be absolutely context free. That is to say, they consist in those aspects of meaning of an utterance that a speaker is able to detect exclusively by virtue of her knowledge on the rules of language without any additional contextual information?

${ }^{2}$ El objetivo de esta cuatripartición es mostrar el carácter problemático de la noción de «significado literal», de su definición y su caracterización. En cambio, P.L. Chiassoni [1999, pp. 580-582] asume implícitamente la tesis de que la noción de significado literal en el ámbito de la lingüística no es problemática sino más bien controvertida, proponiendo cuatro acepciones en las que los lingüistas usarían la locución «significado literal».

${ }^{3}$ Cfr. M. Dascal [1981, p. 175] y [1987, p. 260].

${ }^{4}$ Cfr. D. Marconi [1995, p. 366].

${ }^{5}$ M. Dascal [1987, p. 259].

${ }^{6}$ Cfr. J.J. Katz [1977, p. 14]: «The anonymous letter situation is the case where an ideal speaker of a language receives an anonymous letter containing just one sentence of that language, with no clue whatever about the motive, circumstances of transmission, or any other factor relevant to understanding the sentence on the basis of its context of utterance. [...] We intend to draw a theoretical line between semantic interpretation and pragmatic interpretation by taking the semantic component to properly represent only those aspects of the meaning of a sentence that an ideal speaker-hearer of the language would know in such an anonymous letter situation».

${ }^{7}$ M. Dascal [1987, p. 260]. 
Dascal sitúa, como caracterización complementaria y/o suplementaria a este criterio, el que el mismo denomina «principio de invariabilidad del significado». Escribe Dascal:

The principle of invariabelity of meaning is related to the idea that the literal meaning of an expression is conventionally associated with it by virtue of the rules of language (crystallized in language use), and therefore is constitutive of the expression»s identity as a linguistic unit ${ }^{8}$.

Es habitual sostener que la tesis del literalismo, ingenua y rigurosa al mismo tiempo, encuentra su expresión en la tradición fregeana. La razón principal de esta convicción deriva de la relevancia atribuida por Frege al denominado principio composicional, según el cual el significado de todo enunciado está completamente determinado por el significado de las palabras que lo componen y por las reglas sintácticas de composición ${ }^{9}$. Ahora bien, ni siquiera los escritos de Frege pueden ser considerados un ejemplo riguroso del literalismo: en Frege, en efecto, junto al principio composicional interviene un segundo principio: el principio contextual, según el cual (en la formulación propuesta por el propio Frege) el significado de un término depende del contexto de la totalidad del enunciado en el que aquél se presenta ${ }^{10}$. Así, si por un lado, según el principio composicional, el significado de un enunciado es el resultado del significado de las palabras que lo componen, por otro lado, el significado de las palabras no puede ser identificado con independencia del contexto, aunque sea mínimo, del enunciado en el que figuran.

\subsection{Antiliteralismo moderado}

Con la locución «antiliteralismo moderado» no denomino una única posición homogénea definida con exactitud y precisión, sino más bien una pluralidad de posiciones heterogéneas que (a menudo sin mencionar siquiera la noción de significado literal) tienen por objeto datos y/o fenómenos lingüísticos que a nivel sintáctico y/o semántico y/o pragmático (cuando no incluso a nivel de la mera entonación) interaccionan e interfieren con la mera formulación lingüística de un enunciado, condicionando fuertemente la individualización del significado.

Así (incluso si se quisiera prescindir de aquellos trabajos que identifican en la entonación un factor determinante del significado de un enunciado ${ }^{11}$ ),

${ }^{8}$ M. Dascal [1983, p. 28], (la cursiva es del autor).

9 Acerca de este punto cfr., por ejemplo, M. Dascal [1987, p. 261] y D. Marconi [1995, pp. $377-380]$. 55-56].

${ }^{10}$ Al respecto cfr., por ejemplo, L. Haaparanta [1985, pp. 79-93] y G. Usberti [1995, pp.

${ }^{11}$ A pesar de que su caracterización y definición son dificultosas y controvertidas, el significado entonacional (intonational meaning) es objeto de gran atención en lingüística. Una 
el espectro de los análisis que comparten una matriz común antiliteralista sigue siendo notablemente amplio. En particular, para mencionar únicamente algún ejemplo entre los más relevantes, el antiliteralismo moderado es propio de los trabajos que, a nivel sintáctico, examinan distintos tipos de deícticos (esto es, de enunciados cuyo significado es contingente por la presencia de expresiones autorreferenciales como «yo», «aquí», «hoy», «este») ${ }^{12}$; también de los trabajos que, a nivel semántico, se ocupan de la ambigüedad, de la vaguedad y de otras formas de la denominada open-texture ${ }^{13} \mathrm{o}$ de fenómenos como la anáfora, la metáfora, las implicaturas y el cambio de significado ${ }^{14} ; \mathrm{y}$, finalmente, de trabajos que, a nivel pragmático, se centran en la teoría de los actos de habla y/o en la concepción Wittgensteiniana del significado como uso ${ }^{15}$.

A menudo el antiliteralismo de esta pluralidad heterogénea de trabajos es meramente latente; es decir, no es declarado explícitamente ni perseguido programáticamente.

Por otra parte, el antiliteralismo de esta pluralidad heterogénea de trabajos es seguramente moderado. Lejos de rechazarla, estos trabajos remiten a la noción de significado literal y, si bien dan por descontado cómo deba entenderse esa noción, la mencionan en oposición paradigmática al tipo es-

muestra de ello la ofrecen tanto la investigación pionera de K.L. Pike [1945] como, más recientemente, investigaciones como las de D.R. Ladd [1980], A. Cruttenden [1986] y D. Bolinger [1989]. Una panorámica de algunos de los principales problemas en este tema (así como de las distintas formas de afrontarlos) la ofrece, por ejemplo, J.R. Taylor [1989, ${ }^{2} 1995$, pp. $158-$ 172] que, significativamente, observa: «The failure of successive generations of linguists to come up with a satisfactory set of core meanings for the elements of intonation should not really surprise us. [...] Pike himself suggested an analogy with lexical polysemy. He noted that just as words may have two or more related meanings, "so with intonational contours one must sometimes indicate a central meaning with minor variants from it" (1945: 23)».

${ }^{12}$ Un panorama de algunas de las principales formas de indexicalidad y de deícticos, completada con algunos de los principales interrogantes que éstos pueden suscitar al determinar el significado de un enunciado (o, más correctamente, de una enunciación), puede verse en J. Lyons [1981, pp. 228-231]. M. Prandi [1994], por su parte, sostiene la tesis, algo radical, según la cual cualquier evento comunicativo tiene naturaleza indexical.

13 Alguna referencia bibliográfica sobre algunos de los temas a los que se ha prestado gran atención en la literatura lingüística: F. Waismann [1945, $\left.{ }^{2} 1951\right]$, J.G. Kooij [1971], G. Lakoff [1973], J. Aissen / Hankamer [1977], T. Williamson [1994].

${ }^{14}$ Un interesante abanico de trabajos que tienen por objeto este tipo de fenómenos lingüísticos, seguido de una abundante bibliografía, se puede encontrar en A. Ortony (ed.) [1993]. Merece ser destacada, entre las múltiples referencias bibliográficas ofrecidas, la bibliografía razonada acerca de las metáforas, compilada por J.P. Van Noppen / E. Hols [1990].

${ }^{15}$ La variedad de interpretaciones de los escritos del último Wittgenstein y la pluralidad de lecturas tanto de J.L. Austin [1962] como de J.R. Searle [1969], los dos clásicos más destacados de la teoría de los actos de habla, han dado origen a una literatura imponente y en continuo crecimiento. Una buena visión panorámica introductoria de algunos de los principales aspectos de este campo puede verse en J. Lyons [1981, pp. 169-242]. 
pecífico de significado no literal del que se ocupan (como habitualmente sucede, por ejemplo, en el caso del significado metafórico y figurativo) y/o individualizan en el significado literal uno de los diversos componentes que intervienen en la determinación del significado de un enunciado (como sucede, por ejemplo, con la concepción del significado ilocutivo propia de la teoría de los actos lingüísticos).

Aún dentro de su variedad, estas diversas formas de antiliteralismo moderado (latente) comportan dos consecuencias comunes.

En primer lugar, una atención siempre creciente por las nociones de contexto y de co-testo, consideradas, ambas, ineludibles para una mejor comprensión de la noción de «significado». La primera consecuencia consiste en un paso progresivo desde una concepción literal (textual) a una concepción contextual del significado ${ }^{16} \mathrm{o}$, en otros términos, en un paso progresivo desde una concepción del significado orientada al texto, a una concepción cada vez más orientada al contexto ${ }^{17}$.

En segundo lugar, una reacción crítica (o al menos una incomodidad) respecto de cualquier demarcación neta entre sintaxis, semántica y pragmá-

${ }^{16}$ Una sintética caracterización de estas dos nociones puede verse, por ejemplo, en C. Segre [1986, p. 151]: «The two terms, co-text and context refer, respectively, to verbal environment and situational environment. Adoption of the term co-text [...] stresses the distinction between those elements which are intrinsically textual (or intratextual) and extratextual elements: the latter being proper to extensional semantics (possible worlds, etc.) and to pragmatics (production, reception, interpretation of the text». Y, también, según la formulación de U. Eco [1984, p. 66]: «Un contesto è una classe di occorrenze di catene o gruppi di espressioni (appartenenti a uno o più sistemi semiotici contemporaneamente); si definisce invece co-testo l'occorrenza attuale e specifica di un membro di tale classe». Es interesante destacar que las nociones lingüísticas de «texto», «contexto» y/o «co-testo» han sido objeto de atención específica en algunos trabajos recientes acerca de la interpretación jurídica. Así, por ejemplo, en F. Denozza [1995], en N. Irti [1996] y en algunas de las contribuciones al volumen «Ars Interpretandi» de 1997 dedicado monográficamente al tema «Texto y derecho», como las de A. Belvedere [1997] y F. Viola [1997].

${ }_{17}$ Un panorama interesante de la atención que los lingüistas prestan de forma cada vez más dominante al contextualismo, en un amplio número de trabajos a partir de los años sesenta, puede verse en M. Dascal [1981]. Como denodado defensor del significado literal (al menos en la versión que él mismo propone del literalismo moderado), Dascal ofrece una lectura crítica de la variedad de formas en que ha sido presentado el contextualismo. Y, precisamente, Dascal distingue y toma en consideración formas distintas tanto del contextualismo moderado como del contextualismo radical. Por «contextualismo moderado» Dascal entiende aquella forma de contextualismo que «consists merely in overlooking the role of non-contextual factors, due to exclusive attention paid to one or more types of contextual influence upon the production and interpretation of utterances» (p. 161). Por «contextualismo radical» Dascal entiende, en cambio, aquella forma de contextualismo según la cual «claims that there is no such a thing as a context-free literal meaning of a sentence, present in all its utterances. Contextual factors, therefore, must be made responsible for the whole significance of the utterance, with no context-free anchoring to serve as a starting point. On such a view, there can be no principled grounds for distinguishing between semantics and pragmatics, nor, it seems, between pragmatics and the theory of performance» (p. 166). 
tica por la siempre creciente importancia reconocida al valor semántico de la sintaxis y de la pragmática ${ }^{18}$.

A pesar de estar centrado en el análisis del lenguaje jurídico y en los problemas acerca de su interpretación, una contribución (probablemente involuntaria) al debate que pone en discusión la distinción excesivamente rígida entre semántica y pragmática se debe a Tarello, quien argumenta a favor de la que él mismo denomina «semántica del néustico» ${ }^{19}$. El adversario inmediato y manifiesto de la propuesta de Tarello es la concepción de Hare según la cual, independientemente de las distintas funciones en las que puede ser usado (esto es, independientemente de su néustico), todo enunciado tiene un componente descriptivo (esto es, un frástico) que no está afectado y no se modifica por la fuerza de sus eventuales distintos usos. Son dos los argumentos principales que Tarello opone a la concepción de Hare para mostrar que el néustico de un enunciado normativo (de un precepto) informa y condiciona su frástico: (a) en la interpretación de un enunciado normativo (de una formulación normativa) se debe tener en cuenta la denominada intención del legislador y/o la finalidad que la norma pretende conseguir (su ratio) y (b) la variedad de formas en las que pueden configurarse la voluntad del legislador y, respectivamente, la ratio de las normas jurídicas comporta una pluralidad de formas distintas en las que puede entenderse una formulación normativa ${ }^{20}$.

\subsection{Antiliteralismo radical}

Con la locución «antiliteralismo radical» denomino la posición crítica de los lingüistas frente a la noción de significado literal; esto es, la postura que más abiertamente se opone a la concepción intuitiva habitual de esa noción. El antiliteralismo es una posición expresa porque los trabajos que pueden etiquetarse así hacen de la noción de significado literal su propio objeto de crítica. Pueden distinguirse, dentro del antiliteralismo dos versiones: una aparentemente débil y otra fuerte.

La versión aparentemente débil del antiliteralismo se ejemplifica en el conocido y debatido ataque que Searle dirige, desde una perspectiva stricto

\footnotetext{
${ }_{18}$ Al respecto véase, por ejemplo, J. Lyons [1977, vol. 2, pp. 114-117], U. Eco [1984, pp. 68-70] y [1997, p. xii]. Una formulación epistemológica, por decirlo así, de esta tesis lingüística puede encontrarse en S. Borutti [1983, p. ix] cuando afirma: «il campo del significato non è dato, ma è l'effetto di una varietà di costruzioni teoriche, ed è l'incrocio di questioni emergenti da campi disciplinari diversi». Y, en relación con el lenguaje jurídico, esa misma tesis se formula en M. Jori [1995, pp. 110].

${ }^{19}$ Cfr. G. Tarello [1965].

${ }^{20}$ Acerca del aspecto hermenéutico de la tesis de Tarello, cfr. el reciente debate entre J.J. Moreso [1997 b] y P.L. Chiassoni [1998, pp. 55-73]; sobre sus implicaciones lógicas y epistemológicas, cfr. T. Mazzarese [1990].
} 
sensu filosófica, a la noción de significado literal. La tesis de fondo en el análisis de Searle es que:

for a large number of cases the notion of literal meaning of a sentence only has application relative to a set of background assumptions, and furthermore these background assumptions are not all and could not all be realized in the semantic structure of the sentence ${ }^{21}$.

El objeto principal del análisis crítico de Searle es, pues, precisamente la tesis central de la concepción tradicional del literalismo; esto es, la tesis según la cual:

for every sentence the literal meaning of the sentence can be construed as the meaning it has independently of any context whatever ${ }^{22}$.

Los casos examinados por Searle para demostrar la corrección de su propia afirmación no son, contrariamente a cuanto podía esperarse, los habituales ejemplos de enunciados oscuros y problemáticos, sino, en cambio, ejemplos de casos (aparentemente) claros y simples como: «El gato está sobre el felpudo». Para la comprensión de estos enunciados, según Searle, a pesar de su aparente simplicidad, no se puede evitar la remisión a una pluralidad de asunciones de fondo (de background assumptions). Así, dice Searle:

For a large class of unambiguous sentences such as «The cat is on the mat», the notion of the literal meaning of the sentence only has application relative to a set of background assumptions. The truth conditions of the sentence will vary with variations in these background assumptions [...]. These variations have nothing to do with indexicality, change of meaning, ambiguity, conversational implication, vagueness or presupposition as these notions are standardly discussed in the philosophical and linguistic literature ${ }^{23}$.

Sorprendentemente, sin embargo, a pesar de que la independencia del contexto sea una característica fundamental de la concepción tradicional de la noción de significado literal, Searle trata de limitar, como conclusión de su propio análisis, los efectos destructivos de su ataque y formula el principio de la «relatividad del significado literal»:

When I say that literal meaning of a sentence only has application relative to the coordinate system of our background assumptions, I am not denying that

${ }^{21}$ J.R. Searle [1978, ${ }^{2} 1979$, p. 120].

${ }^{22}$ J.R. Searle [1978, ${ }^{2} 1979$, p. 117]. Se formulan ulteriores argumentos contra esta tesis de la teoría tradicional en J.R. Searle [1980] y, desde una perspectiva aún más radical, en R.W. Gibbs [1982, pp. 23-26].

${ }^{23}$ J.R. Searle [1978, ${ }^{2} 1979$, p. 125]. Argumentos parecidos son desarrollados por Searle (pp. 126-131) con relación a los que él mismo denomina enunciados «imperativos» y «optativos»; enunciados acerca de los que Searle estudia, respectivamente, las «condiciones de obediencia» y las «condiciones de satisfacción». (En el caso del enunciado «el gato está sobre el felpudo» Searle menciona, como background assumptions, que el gato y el felpudo no estén flotando en el espacio y la presencia de la fuerza de la gravedad.) 
sentences have literal meanings. Literal meaning, though relative is stell literal meaning ${ }^{24}$.

La versión fuerte del antiliteralismo radical puede ejemplificarse, por su parte, en el ataque estricto que, desde una perspectiva de cariz más psicolingüístico que propiamente filosófico como el de Searle, han llevado a cabo tanto Rumelhart como su discípulo Gibbs. A diferencia de lo que sucede con el principio de Searle de la «relatividad del significado literal» y con los trabajos del literalismo moderado, según la versión fuerte del antiliteralismo el significado literal no es siquiera el término frente al que elaborar alguna de las formas posibles de significado no-literal ni alguno de los diversos elementos que intervienen en la individualización del significado de cada expresión lingüística. En efecto, según Gibbs:

Not only is difficult to show that all sentences have well-defined literal meanings, but even in cases where we supposedly can, one finds that these are not always used in understanding language ${ }^{25}$.

Es más, aunque aparentemente la pretensión expresa sea únicamente precisar que el alcance de sus propios argumentos es principalmente de carácter psicolingüístico, Gibbs afirma que:

Discussions of literal meaning in linguistics and philosophy are not directly applicable to the concerns of a psychological theory of meaning. Traditional theories of literal meaning as context-free meaning, and revised notions of literal meaning as sentence meaning relative to a set of background assumptions, do little to explain what people do in understanding language. From a psychological perspective, the semantic competence of speakers and hearers can not be seen as knowledge apart from its actual use in speaking, listening, and acquiring language ${ }^{26}$.

La posición de Gibbs sigue de cerca a la de Rumelhart que, a diferencia de la distinción trazada por el análisis (antiliteralista moderado) de Searle y de un gran número de trabajos del literalismo moderado, pone en duda

${ }^{24}$ J.R. Searle [1978, ${ }^{2} 1979$, p. 132]. Que esta conclusión es dudosa y problemática, y no el resultado obvio de la argumentación desarrollada, parece confirmarse por la pluralidad de lecturas enfrentadas de las que ha sido objeto. Así, por ejemplo, mientras que R.W. Gibbs [1984] ataca ese análisis porque no deja de tomar en serio la noción de significado literal, J.J. Katz [1981] y M. Dascal [1981], en cambio, lo rechazan por su corte crítico y le replican con la defensa de la concepción tradicional de la noción de significado literal, el primero, y con la propuesta de una caracterización alternativa propia, el segundo. O, por último, F. Schauer [1991, pp. 57-58] menciona el análisis de Searle para sostener una presunta «autonomía semántica», esto es: «the way in which language carries something by itself, independent of those who use it in particular occasions».

${ }^{25}$ R.W. Gibbs [1984, p. 299].

${ }^{26}$ R.W. Gibbs [1984, pp. 299-300]. En una réplica a M. Dascal [1987], R.W. Gibbs [1989, p. 244] reformula la misma tesis en términos incluso más claros: «Literal meaning, whether viewed as compositional or as conventional meaning, is not an obligatory stage of analysis in psychological process models of language comprehension. People may phenomenologically identify some meanings as literal ones, but these are products of understanding and do not imply that different cognitive mechanism drive the comprehension of literal figurative discourse». 
the existence of a sharp distinction between what an utterance might mean (that is, its literal meaning) and what that utterance is, or can be, used to convey ${ }^{27}$.

$\mathrm{Y}$, precisamente, Rumelhart pone en duda la distinción entre «sentence meaning» $\mathrm{y}$ «utterance meanning ${ }^{28}$, en la terminología de Searle, en la medida en que:

the same problems arise for literal language as for figurative language. In both cases, what is conveyed is not easely determined from the meanings of the individual lexical items of the utterance, and in both cases, the interpretation seems to depend on knowledge well beyond definitions of the terms involved. There are no rules whereby lexical meanings can be combined to generate conveyed meanings [...] the processes involved in the comprehension of nonfigurative language are no less dependent on knowledge of the world than those involved in figurative language ${ }^{29}$.

\subsection{Literalismo moderado}

Como ya se ha señalado ( $§ 1$.), la locución «literalismo moderado» fue sugerida originariamente por Dascal para referirse a su propia defensa de la noción de significado literal contra los ataques más radicales como, por ejemplo, los ya mencionados de Searle, Rumelhart y Gibbs. Del mismo modo que Dascal, uso la locución «literalismo moderado» para denominar la

${ }^{27}$ E. Rumelhart [1979, ${ }^{2} 1993$, p. 71] (la cursiva es del autor). Rumelhart se remite explícitamente a J.M. Sadock [1979, ${ }^{2}$ 1993] y a J.R. Searle [1979, $\left.{ }^{2} 1993\right]$. Algunos años después de la publicación del volumen sobre la metáfora que incluye, entre otros, los tres trabajos recién mencionados, Ortony coordina una segunda edición del volumen, ampliada y actualizada. Entre los nuevos trabajos, uno de Lakoff (como el de Rumelhart) ataca de forma estricta y radical la distinción entre significado literal y figurado. En particular, según G. Lakoff [1993, p. 204]: «A major assumption that is challenged by contemporary research is the traditional division between literal and figurative language, with metaphor as a kind of figurative language. This entails, by definition, that: what is literal is not metaphorical. In fact, the word "literal" has traditionally been used with one or more of a set of assumptions that have since proved to be false».

${ }^{28}$ Con distintas denominaciones, la distinción entre sentence meaning y utterance meaning se presenta a menudo en lingüística, aunque (como por ejemplo en el análisis de Rumelhart) no siempre es aceptada aproblemáticamente. Citando a J. Lyons [1981, p. 24]: «The distinction between sentence-meaning and the meaning of utterances and texts [...] cannot be taken for granted in the way that the one between word-meaning and sentence-meaning can. Not only is it less familiar to laymen. It is also the subject of a good deal of controversy, not to say confusion, among specialists». En la propia formulación de Lyons la distinción se presenta así (p. 29): «Sentence-meaning [...] is related to the utterance-meaning by virtue of the notion of characteristic use, but it differs from it by virtue of the fact that the meaning of a sentence is independent of the particular contexts in which it may be uttered. To determine the meaning of an utterance, on the other hand, we have to take contextual factors into account».

${ }^{29}$ D.E. Rumelhart $\left[1979,{ }^{2} 1993\right.$, p. 76]. Cabe destacar que esa afirmación, referida, por otra parte, a la distinción de Searle entre sentence meaning y utterance meaning, recuerde fuertemente a la concepción del mismo Searle de las background assumptions que influencian el presunto significado literal de todo enunciado. 
posición de los lingüistas que (a pesar de ser conscientes de las diversas perplejidades a las que puede dar lugar la concepción tradicional) sostienen que debe mantenerse, aunque sea reformulada, alguna noción de significado literal.

De acuerdo con esta posición, Eco (que ha investigado muchas formas de significado no-literal y de significado contextual) afirma que todo discurso sobre la libertad de la interpretación debe empezar con una defensa del significado literal ${ }^{30}$.

Ahora bien, Dascal sostiene que la noción tradicional de significado literal se define en términos demasiado restrictivos y que es necesaria una reformulación de la misma que abandone

the attempt to provide a set of necessary and sufficient conditions for something to be a literal meaning. Instead, a number of conditions and the corresponding criteria are described which are semantically relevant to the characterization of the notion of literal meaning so that, when a large number of these conditions are satisfied, an aspect of meaning can be reliably seen as belonging to literal meaning, but no single condition is strictly necessary in the sense that its absence would ipso facto prevent the aspect of meaning from being so described $^{31}$.

Aunque pueda parecer simple y convincente, no está claro si esta reformulación propuesta por Dascal permite una defensa de la noción de significado literal. No está claro, en efecto, cómo una noción como ésta, consistente en un número impreciso de condiciones (ninguna de las cuales es necesaria o suficiente) puede oponerse, como pretende Dascal, al contextualismo radical (esto es, la concepción según la cual «all of our understanding of a language would have to be accounted by «contexts» alone» ${ }^{32}$ ), permitiendo trazar una nueva línea de demarcación entre la semántica y la pragmática. La duda se refuerza si se toma en cuenta lo que Dascal sostiene en un trabajo, escrito con Wróblewski, sobre la claridad de los textos jurídicos y la interpretación. Dascal y Wróblewski, en efecto, después de una relectura crítica tanto de la concepción tradicional de los juristas como de algu-

${ }^{30}$ Cfr. U. Eco [1990, ${ }^{2} 1995$, p. 26]. En lo que respecta a la interpretación jurídica, una posición parecida se ha sostenido, por ejemplo, por los autores que, a pesar de ser conscientes de las dificultades con las que tropieza todo intento de definir con precisión la noción de significado literal, distinguen dos estadios (dos niveles distintos) de la interpretación de los textos jurídicos: un primer estadio que tiene por objeto el literalismo textual y un segundo estadio, profundo, que tiene por objeto el contexto (los distintos contextos posibles). En este sentido, por ejemplo, se ha expresado recientemente E. Diciotti [1999, pp. 345-360]. Merece también ser mencionado, tanto por la claridad con la que traza la distinción como por el análisis del tema estudiado (el argumento a contrario), G. Carcaterra [1994].

${ }^{31}$ M. Dascal [1987, p. 260].

${ }^{32}$ M. Dascal [1987, p. 276], (la cursiva es del autor). 
nas de las posiciones contrarias a la misma, proponen una caracterización distinta de la claridad de los textos jurídicos, declaradamente pragmática. Precisamente:

the notion of clarity [...] is a pragmatic concept. It is not an inherent qualification of a legal text, but depends upon its use in a given communicative situation. The relevant aspects of such a situation include the users of the language, their epistemic and axiological attitudes, as well as the specific forms of context and co-text ${ }^{33}$.

\subsection{Un balance tentativo}

Literalismo, antiliteralismo moderado (latente), antiliteralismo radical (manifiesto) y literalismo moderado son los términos que he usado para designar los cuatro elementos de una posible panorámica, en la literatura lingüística del siglo $\mathrm{XX}$, de algunas de las principales posiciones sobre la noción de significado literal.

Ahora bien, a los efectos de resumir y concluir las observaciones que preceden, resulta plausible afirmar que el literalismo puede entenderse (aun cuando, quizás, nadie lo haya defendido en su versión más radical) como la concepción que sostiene que el significado literal es todo lo que se necesita para definir el significado. En otros términos, si bien sus condiciones necesarias y suficientes están lejos de ser definidas claramente y precisadas rigurosamente, el significado literal es considerado suficiente para identificar el significado de una expresión lingüística. Según esta concepción, «significado literal» resulta ser, pues, una expresión de alguna forma pleonástica, en la medida en que el significado no puede ser otra cosa que literal.

La concepción opuesta (que, a diferencia de la concepción radical del literalismo, sí ha sido explícitamente enunciada y defendida) es el antiliteralismo radical (manifiesto). Según esta concepción, «significado literal» no es una expresión pleonástica, sino un oximorón. En efecto, según el antili-

${ }_{33}$ M. Dascal / J. Wróblewski [1988, p. 221]. Es más, siempre según Dascal y Wróblewski (p. 220): «The linguistic and meta-linguistic co-text [...] of legal discourse has, in addition to the fuzziness [...], several specific characteristics that may generate doubts triggering an interpretative process. These include, for example, the linguistic differentiation of kinds of legal "speech acts" (e.g., pleading, ruling, interrogating, witnessing, indicting, sentencing, legislation, etc.) and "genders" (laws, statutes, acts, procedural rules, precedents, etc.) whose proper recognition provides the indispensable meta-linguistic frame for correct understanding». Y, en referencia a un contexto de tipo sistémico y a un contexto de tipo funcional, añaden: «A legal text which formulates legal rules is always understood in the context of the legal system to which these rules belong. It is usually assumed that such system has -or should have- the properties of consistency, coherence and eventually completeness and lack of redundancy. [...] A legal text in which legal rules are formulated is created and is operative in a functional context. This context is rather complex because its components are all those extra-systemic factors which are thought of as relevant for the understanding of the legal text». 
teralismo radical el significado es una función de una pluralidad de variables distintas, entre las que el significado literal tiene un papel (si es que tiene alguno) absolutamente subsidiario.

Tanto para el antiliteralismo moderado (latente) como para el literalismo moderado, «significado literal» no es un oximorón ni una expresión pleonástica. Sin embargo, las dos concepciones no son equivalentes. Aunque pueda resultar sorprendente, el literalismo moderado es una concepción mucho más prudente que el antiliteralismo moderado. En efecto, tratando de limitar su impacto, el literalismo moderado no ignora en absoluto la diversidad de críticas de las que es pasible la noción de significado literal. Así, la concepción alternativa de significado literal que se sugiere resulta, como en el caso de la propuesta de Dascal, una noción débil, ampliamente indeterminada.

\section{Los juristas y las nociones de «significado literal» $\mathbf{y}$ de «interpretación literal»}

Parece claro, a partir de la constatación de las diversas dudas de los lingüistas, que la noción de significado literal no permite fundar un criterio interpretativo aceptable de forma incontrovertida. Como máximo, tal como se sugiere desde la perspectiva del literalismo moderado, su «papel fundamental» (no importa en qué medida subsidiario) debe circunscribirse, como sostiene Dascal, al de conducir

the hearer to the identification of the relevant items of contextual information which have to be used in order to come up with an interpretation ${ }^{34}$.

Esto es, el significado literal asume el papel de mero instrumento selectivo y/o evocativo de la diversidad de elementos no-literales (es decir, de elementos no puramente semánticos) que intervienen en la determinación del resultado de cualquier proceso interpretativo. Así pues, incluso desde la perspectiva del literalismo moderado, el significado literal es considerado como un punto de partida, pero no necesariamente como el marco en el que circunscribir la interpretación. Los propios defensores del literalismo moderado son, en efecto, conscientes del hecho de que

the final meaning need not be a part of the final interpretation of any given utterance (i.e., of what the addressee decides to be its speaker's meaning). In many cases its contribution is entirely absent from the final interpretation (e.g., in some cases of irony $[\ldots])$. In other cases, it hardly contributes any «content» whatsoever to the speaker's meaning (e.g., when someone utters in an appropriate context a series of nonsense sounds). ${ }^{35}$

\footnotetext{
${ }^{34}$ M. Dascal [1987, p. 262].

${ }^{35}$ M. Dascal [1987, p. 262].
} 
Las muy variadas dudas que los lingüistas han mostrado acerca de la noción de significado literal, a pesar de estar centradas en fenómenos que los juristas podrían estar tentados a considerar como marginales del uso del lenguaje común, tienen también, en cambio, una indiscutible importancia para el lenguaje jurídico y condicionan la maraña de problemas referidos a su interpretación.

Las dudas de los lingüistas, en efecto, no afectan sólo al lenguaje jurídico sino que adquieren específicos trazos distintivos por la peculiar naturaleza del lenguaje jurídico: en parte lenguaje natural y en parte lenguaje técnico especializado ${ }^{36}$.

Ahora bien, como ya ha sido señalado, no está claro qué pretenden los juristas cuando prescriben y/o, en función de los casos, afirman y/o recomiendan que la interpretación se funde en el significado literal o significado propio de las palabras. No sólo no está claro, como es obvio, por el propio carácter problemático de la noción de significado literal, sino también por dos razones adicionales: (a) el uso no unívoco que los juristas hacen del término «literal» y/o de otros términos asumidos como sinónimos de «literal» (§ 2.1.) y (b) la pluralidad de concepciones antagónicas que tienen los juristas del proceso interpretativo ( $\$ 2.2$.).

\subsection{Distintas concepciones de «literal»}

Si se pretende encontrar un rechazo del criterio interpretativo fundamentado en el significado literal, Williams ofrece una formulación claramente drástica del mismo:

The literal rule is a rule against using intelligence in understanding language. Anyone who in ordinary life interpreted words literally, being indifferent to what the speaker or writer meant, would be regarded as pedant, a mischief-maker or an idiot ${ }^{37}$.

Concebido y rígidamente definido como el anàlogon del principio composicional (es decir, del principio según el cual el significado de un enunciado está determinado únicamente por el significado de las palabras que lo componen), el criterio interpretativo que se funda en la noción de significado literal no puede substraerse fácilmente a una crítica severa como la de Williams.

No obstante, para atenuar, aunque ciertamente no para eliminar, una crítica tan definitiva frente a cualquier directiva del legislador que prescriba la

\footnotetext{
${ }^{36}$ En lo que se refiere a la traducción del lenguaje jurídico, la importancia de la compleja interacción entre las características propias del lenguaje común y las del lenguaje técnico especializado es subrayada en T. Mazzarese [1996, pp. 403-405].

${ }^{37}$ G. Williams [1945, ${ }^{11} 1982$, p. 105].
} 
interpretación literal y/o frente a cualquier operador jurídico que pretenda atenerse a ella al aplicar el derecho y/o frente a cualquier teórico del derecho que recomiende su uso, debe decirse que en la terminología de los juristas «interpretación literal» no designa una noción unívoca; esto es, no designa un criterio interpretativo claramente definido. En efecto, son diversas las concepciones que los juristas manejan del literalismo y no son siempre unívocas las expresiones que usan para denominarlas.

\subsubsection{Distintas concepciones de literalismo}

No intentaré aquí sugerir una tipología de las distintas formas posibles de interpretación literal ${ }^{38}$ ni proponer un abanico de los diversos sentidos en que la expresión «interpretación literal» es usada en el lenguaje de los juristas ${ }^{39}$. Me limitaré, simplemente, a ofrecer una ejemplificación de la falta de univocidad de «literal» en el lenguaje de los juristas, partiendo de una contribución indudablemente significativa para el análisis comparado de la interpretación de la ley («statutory interpretation»), coordinada, no hace muchos años, por MacCormick y Summers.

Concebido y organizado de forma rigurosa, el análisis comparado de las características peculiares de la interpretación de la ley en nueve países (Argentina, Finlandia, Francia, Italia, Polonia, República Federal Alemana, Suecia, Reino Unido y Estados Unidos) es realizado por los distintos estudiosos de cada país siguiendo una misma falsilla: un esquema común de las preguntas que, de forma preliminar, han sido indicadas como principales no sólo a los efectos de que las diversas contribuciones resulten suficientemente exhaustivas en la descripción de cada situación nacional concreta, sino también, en especial, suficientemente homogéneas para hacer posible una comparación significativa.

${ }^{38}$ Una tipología de sus posibles configuraciones, más que una mera ejemplificación de las distintas formas en que los juristas entienden la noción de interpretación literal, es propuesta por L. Lombardi Vallauri [1971, ${ }^{2} 1981$, pp. 55-58]. Partiendo de las distinciones dicotómicas más habituales en los análisis acerca de la interpretación jurídica, Lombardi Vallauri, recurriendo a un procedimiento combinatorio, distingue 24 tipos de interpretación, 6 de los cuales representan formas distintas de interpretación literal. En concreto: (1) «interpretazione oggettiva storica letterale settoriale», (2) «interpretazione oggettiva storica letterale sistematica», (3) «interpretazione oggettiva evolutiva letterale settoriale», (4) «interpretazione oggettiva evolutiva letterale sistematica», (5) «interpretazione soggettiva storica letterale settoriale» y (6) «interpretazione soggettiva storica letterale sistematica».

${ }^{39}$ C. Luzzati [1990, pp. 208-228] presenta un elenco de siete formas distintas en que los juristas entienden esa expresión. Véase, también, la distinción trazada recientemente por P. L. Chiassoni [1999, pp. 583-585] entre cuatro sentidos distintos en que los juristas usan «significado literal». 
El esquema común consiste en veinte preguntas formuladas analíticamente, cuando no articuladas posteriormente en subpreguntas, más una pregunta cero ${ }^{40}$.

Como confirmación (si fuera necesaria) de la importancia que continua teniendo el literalismo en la interpretación jurídica, a pesar de todas las reservas de los lingüistas, el término «literal» («literal») aparece en cuatro de las veinti(una) preguntas incluidas en el esquema. En particular, en la formulación de la pregunta número 3, aparece la locución «literal meaning»:

Define any key terms such as «literal meaning», «contextual meaning», «intention of legislature» (several senses, if so used) and «purposive interpretation» ${ }^{41}$.

En la formulación de la pregunta número 6 aparece, en cambio, la locución «literary or ordinary meaning of words in the statute»:

In choosing between conflicting arguments, do the highest courts commonly give primary emphasis to what they assume to be the literal or ordinary meaning of words in the statute? ${ }^{42}$

En la formulación de la pregunta número 7, aparece otra variante distinta: «literally (formally)»:

If hierarchical rules of priority are applied [...] are they interpreted and applied only literally (formally) or are they interpreted and applied also in the light of the substantive considerations or rationales reflected in the conflicting statutes or norms $[\ldots]$ emergent in the circumstances? ${ }^{43}$

Por último, en la formulación de la pregunta número 19, figura de nuevo la locución (que ya aparecía en la formulación de la pregunta número 7): «ordinary or literal meanings of statutory words». La noción de «significado literal» tiene un papel clave en la formulación de la pregunta número 19; el tipo de análisis crítico requerido a cada contribución es, en efecto, ejemplificado recurriendo a la siguiente comparación entre el sistema jurídico inglés y el norteamericano:

English courts generally give more weight to interpretative arguments based on the ordinary or literal meanings of statutory words than do American courts. [...] This does not necessarely mean that either the English or the American emphasis on ordinary meaning or the American emphasis on purpose is unjustified. Thus, the English emphasis on ordinary meaning may be justified, given such institutional factors in England (not present to the same degree in USA) as (1) more highly professional drafting (2) executive control over statutory texts

${ }^{40}$ Bajo el título: Appendix: Final Version of the Questions, Comparative Statutory Interpretation. Project 1 November 1989, el esquema se reproduce al final del volumen: N. MacCormick / R. S. Summers (eds.) [1991].

${ }^{41}$ N. MacCormick / R. S. Summers (eds.) [1991, p. 546], (la cursiva es mía).

${ }^{42}$ N. MacCormick / R. S. Summers (eds.) [1991, p. 546], (la cursiva es mía).

${ }^{43}$ N. MacCormick / R. S. Summers (eds.) [1991, p. 547], (la cursiva es mía). 
so that they embody fewer ambiguities traceable to the necessity for compromise and (3) active legislation to correct judicial misinterpretation ${ }^{44}$.

No hay univocidad (en la formulación de las preguntas recién mencionadas) entre las distintas ocurrencias de «literal»y de «significado literal». (Como es fácil imaginar, la falta de univocidad podría ejemplificarse de forma mucho más numerosa si, más allá de las preguntas, se tomaran también en consideración las respuestas ofrecidas por las contribuciones al volumen.)

Limitándose, sin embargo, a la formulación de las cuatro preguntas recién mencionadas, el uso del término «literal» no es unívoco, en primer lugar, porque el recurso a los términos «ordinario» $\mathrm{y}$ «formal» como ulterior calificación y/o como sinónimos de «literal» no hace más que alterar, de hecho, el significado que tiene «literal» (cualquiera que sea la forma en que se lo entienda) cuando este término es usado por sí solo; y, en segundo lugar, porque los términos «ordinario»y «formal» no son ellos mismos sinónimos $\mathrm{y}$, por tanto, si se usan para calificar el término «literal», alteran su significado (cualquiera que sea la forma en que se lo entienda) de dos formas distintas.

2.1.2. Variedad de denominaciones de concepciones diversas del literalismo

«Abstracto», «formal», «gramatical» ${ }^{45}$, «inmediato» ${ }^{46}$, «lingüístico» ${ }^{47}$, «obvio» ${ }^{48}$, «ordinario», «patente» ${ }^{49}$, «propio», «semántico» ${ }^{50}$, «semiótico» ${ }^{51}$, «textual» ${ }^{52}$ son sólo algunos de los muchos términos utilizados para denominar concepciones distintas del literalismo; esto es, concepciones distintas de

${ }^{44}$ N. MacCormick / R. S. Summers (eds.) [1991, p. 550], (la cursiva es mía).

${ }_{45}$ Tanto «sentido gramatical» como «método gramatical» aparecen, por ejemplo, en R.J. Vernengo [1994].

${ }^{46}$ Con «inmediato», traduzco el término inglés «direct». «Direct meaning» $\mathrm{y}$ «direct understanding» aparecen, por ejemplo, en M. Dascal / J. Wróblewski [1988].

${ }^{47}$ Además de los trabajos mencionados en adelante en el texto, «linguistic meaning» aparece, por ejemplo, en J. Wróblewski [1992, pp. 97-100] y en B. Bix [1993, e.g. p. 76].

48 «Obvious meaning» $\mathrm{y}$ «obvious interpretation» aparecen, por ejemplo, en N. MacCormick [1978, pp. 203-213] y en Z. Bankowski / N. MacCormick [1991, pp. 365-366].

${ }^{49}$ Con «patente» traduzco el término inglés «plain». «Plain meaning» aparece, por ejemplo, en N. MacCormick [1978, p. 204, pp. 208-209] y en B. Bix [1993, por ejemplo, pp. 67, 74-75, 156].

50 «Significado semántico» aparece, por ejemplo, en B.S. Jackson [1999].

${ }^{51}$ «Semiotic interpretation» aparece en R. Alexy / R. Dreier [1991, p. 82]: «The semiotic interpretation -in Germany usually called «Wortlaut», «philologische» or «grammatische Auslegung»- requires an investigation into the semantic content and the syntactic structure of a norm».

${ }^{52}$ La expresión «textual approach» aparece, por ejemplo, en I. Sinclair [1973, ${ }^{2} 1984$, p. 114]. 
la noción de significado literal y/o del criterio literal de la interpretación ${ }^{53}$. No obstante, raramente son definidos de forma clara y explícita y es fácil mostrar que todos los términos de esta lista asistemática son usados, en el lenguaje de los juristas, en una pluralidad de acepciones no coincidentes.

Dos ejemplos serán suficientes para confirmar esta afirmación y para intentar trazar, en la heterogeneidad de usos de esta variedad de términos, una distinción entre dos tipos de usos principales.

Un primer ejemplo se refiere al término «lingüístico». Al menos en un contexto bastante circunscrito y homogéneo como el del ya mencionado análisis comparado sobre la interpretación de la ley, coordinado por MacCormick y Summers, «linguistic» es usado en un mínimo de dos sentidos distintos.

En el primer sentido, que aparece por ejemplo en la contribución de Peczenik y Bergholz, «lingüístico» parece usarse simplemente como sinónimo de «literal» ${ }^{54}$.

En el segundo sentido, en cambio, «lingüístico» es utilizado como término de género para denominar una pluralidad de criterios interpretativos centrados, cada uno según su propia especificidad, en aspectos distintos de la formulación lingüística de una ley. En este sentido, el término se utiliza en diversas contribuciones como, por ejemplo, las de Aarnio ${ }^{55}$, Bankowski y MacCormick ${ }^{56}$, Troper, Grzegorczyk y Gardies ${ }^{57}$ y Zuleta-Pucerio ${ }^{58}$.

${ }^{53}$ Un claro ejemplo de la distinción trazada entre dos formas distintas de entender el criterio literal de la interpretación, en función de la oposición entre «significado literal» y «significado propio de las palabras» puede encontrarse en N. Irti [1996]. En su cuidadoso análisis de la interpretación de los contratos, Irti sostiene, en efecto, que en lo que concierne al ordenamiento jurídico italiano las directivas sobre interpretación de los contratos, por un lado, y las directivas sobre interpretación de la ley, por el otro, llevan a dos formas distintas de entender el criterio literal. Y precisamente, afirma Irti: «L'art. 12 prescrive all'interprete di adottare il "significato proprio delle parole secondo la connessione di esse". Il criterio della connessione, o dell'unità sistemica, designa l'uso del contesto verbale, che nel contratto si restringe alle clausole del singolo accordo (art. 1363), e nella legge si dilata a tutte le norme di un dato ordinamento. Ma "significato proprio" e "senso letterale" sono espressioni identiche, e si riferiscono al medesimo fenomeno? [...] Senso (o significato) letterale, contrapposto alla comune intenzione, è il senso del codice generale: La letteralità indica una sorta di visibilità sociale, sicché tutti i parlanti [...] attribuiscono alla parola lo stesso contenuto. Significato proprio, messo accanto ad intenzione del legislatore, è il significato corretto: La proprietà indica l'adeguatezza tecnica, la congruenza con la materia in esame» (pp. 150-15, la cursiva es del autor).

${ }^{54}$ A. Peczenik / G. Bergholz [1991, p. 314] escriben: «Linguistic interpretation. This is often called "interpretation following the words of the law" (Swed. lagens ordalydelse; the word "ordalydelse" corresponds to German "Wortlaut"). More abstract and general terms, such as "semantic" occur seldom, mostly in theoretical contexts».

55 A. Aarnio [1991, pp. 133-134] distingue dos tipos de argumentos (criterios) lingüísticos: «semánticos» $\mathrm{y}$ «sintácticos».

${ }^{56}$ Z. Bankowski / N. MacCormick [1991, pp. 365-366] escriben: «Linguistic arguments. Either or both syntactic and semantic arguments are always available. Linguistics arguments in interpretative reasoning are commonly singalled by resort to such expressions as the literal 
Un segundo ejemplo de la variedad de sentidos in que se utilizan términos alternativos a «literal», está referido a «ordinario».

En particular, «ordinario», a veces, es usado como sinónimo de «literal». Como ya he señalado, puede encontrarse este uso en la formulación de la pregunta número 19 del también citado análisis comparado sobre la interpretación de la ley editado por MacCormick y Summers. Más precisamente, en la formulación de esa pregunta, en sustitución del término «literal», se usa, en primer lugar, la expresión «ordinary or literal» y, posteriormente, el término «ordinary» por sí solo.

Otras veces, en cambio, según un uso radicalmente distinto, «significado ordinario» no es asimilado, sino netamente distinguido de la noción de «significado literal».

En este segundo sentido, el término se utiliza, por ejemplo, en la formulación del artículo 31 de la Vienna Convention on the Law of Treaties. El primer párrafo de ese artículo reza: «A treaty shall be interpreted in good faith in accordance with the ordinary meaning to be given to the terms of the treaty in their context and in the light of its object and purpose». Después, el segundo párrafo establece lo que, a parte del texto, se debe considerar constitutivo del contexto; el tercero, aquello que debe tenerse en cuenta más allá del contexto y, por último, el cuarto párrafo señala en qué casos «special meaning is to be given to a term if it is established that the parties so intended».

Ahora bien, aunque no se haga una mención explícita de ello, está claro que, en la redacción del artículo 31 de la Convención de Viena, la locución «ordinary meaning» no se usa simplemente como sinónimo de «significa-

$[\ldots]$ or ordinary $[\ldots]$ or obvious $[\ldots]$ or "plain" meaning of statutory words and provisions. [...] There are different varieties of linguistic argument, as follows: (1) A strong version is one where arguments are given to show that the preferred reading is, upon due reflection, the only possible reading of the text in context, and thus must prevael as the "plain" or "obvious" meaning of the statute. We may call this the "argument from the only possible meaning". (2) Arguments may be given to show that the preferred reading is the only obvious, or the more obvious, among a range of linguistically possible readings, the circumstances being such that no sufficient reason obtains for displacing the presumption in favour of the more "plain meaning" or the more "obvious meaning". We call this the "argument from undisplaced obvious meaning" [...]; (3) The argument from logical absurdity may be deployed to show that the statutory text contains a self-contradiction, which no possible (and otherwise acceptable) reading of the text can evade. [...] These arguments may lead on to «arguments from necessary implication».

${ }^{57}$ M. Troper / Chr. Grzegorczyk y J.-L. Gardies [1991, p. 182] escriben: «Linguistic arguments are based on the language in which the text is written. [...] When courts use linguistic arguments, they sometimes speak of "literal meaning" of the statute, but by this expression they can refer to several entirely different things.»

${ }^{58}$ E. Zuleta-Pucerio [1991, p. 43] distingue dos tipos de argumentos (criterios) lingüísticos: «semánticos» $\mathrm{y}$ «sintácticos». 
do literal» sino, en todo caso, como una expresión genérica que remite a una vasta suma de los criterios de interpretación jurídica más clásicos ${ }^{59}$. En otros términos, no obstante o quizás precisamente por su formulación tan detallada, el criterio del significado ordinario resulta indudablemente sincrético: un criterio que combina y asimila indistintamente un gran numero de criterios interpretativos heterogéneos ${ }^{60}$.

No es distinta la conclusión que se obtiene a partir de un análisis de Summers y Marshall realizado en 1992. En ese análisis la noción de «significado ordinario» se distingue explícitamente de la de «significado literal» así como de las nociones de ««plain» or «clear» meaning, as these terms are often used by judges and other» y de la noción de «technical meanings, legal or non-legal» ${ }^{61}$.

El análisis de Summers y Marshall especifica, además, qué debe entenderse por significado ordinario:

the meaning which a competent, knowledgeable, purposeful and informed user of ordinary language would give to ordinary words of the statute in issue on the basis of what we will call the resources of ordinary language argumentation ${ }^{62}$.

Esta definición, conjuntamente con algunos de los argumentos adoptados para defender el criterio interpretativo del significado ordinario de los ataques de los que ha sido objeto, llevan (como en el caso del artículo 31 de la Convención de Viena) a una caracterización de «significado ordinario» no unívoca, sino ecléctica. Esa caracterización se revela simplemente como una síntesis de una vasta gama de los criterios interpretativos más clásicos. En efecto, citando cuanto escriben los propios Summers y Marshall:

The various resources to be brought to bear by ordinary language user include: general linguistic competence, dictionaries, grammar books, the bearing

${ }^{59}$ Respecto del artículo 31 de la Convención de Viena la afirmación de que «significado ordinario» no debe entenderse como «significado literal» es formulada, por ejemplo, por I. Sinclair [1973, ${ }^{2} 1984$, p. 121]: «This "ordinary meaning" does not necessarely result from a pure grammatical analysis. The true meaning of a text has to be arrived at by taking into account all the consequences which normally and reasonably flow from that text. Furthermore, there is no such thing as an abstract ordinary meaning of a phrase, divorced from the place which that phrase occupies in the text to be interpreted».

${ }^{60}$ Probablemente ésta es la razón por la que, como subraya I. Sinclair [1973, ${ }^{2} 1984$, p. 114]: «There are few topics in international law which have given rise to such extensive doctrinal disputes as the topic of treaty interpretation».

${ }^{61}$ Cfr. R. S. Summers / G. Marshall [1992, pp. 215-216].

${ }^{62}$ R. S. Summers / G. Marshall [1992, p. 215]. En la medida en que la noción de «competent, knowledgeable, purposeful and informed user of ordinary language» remite a, y/o presupone, alguna forma de «intersubjective perspective of an interpretative community», no se puede dejar de compartir cuanto señala, de forma innegablemente obvia, M. Rosenfeld [1990, p. 1213], quien sostiene que: «the intersubjective perspective of an "interpretative community" can only prevail through the suppression of difference and the subordination of dissenting other. Indeed [...] legal interpretation becomes manifestly problematic because of conflict and fragmentation within the interpretative community» (la cursiva es del autor). 
on a general context of usage, general knowledge of the language user, purposive analysis drawing at least on immediate purposes in the circumstances, the drafter»s knowledge of usage in parallel circumstances in ordinary life, special factual knowledge, reminders of factual considerations already familiar, the use of hypothetical analysis, analogy, standards of consistency and systematic reflection. [...] In the end we might even reconceptualize and retitle our subject not as «the argument from ordinary meaning» but as a variety of language-oriented arguments for refining meaning or settling doubts about ordinary words ${ }^{63}$.

A los efectos de concluir estas observaciones sobre los diversos usos de los distintos términos que remiten a la noción de significado literal, se puede proponer una distinción entre dos tipos principales de elecciones terminológico-conceptuales. La clasificación que propongo, haciendo referencia a las cuatro posiciones examinadas de los lingüistas acerca del significado literal, es la que distingue entre una forma de literalismo jurídico radical y una forma de literalismo jurídico moderado.

El primer tipo (denominado literalismo jurídico radical) comprende todos los usos lingüísticos que aparentemente asumen una concepción restringida del significado literal (como es el caso del primero de los dos usos mencionados de «interpretación lingüística»y, respectivamente, de «significado ordinario»); el segundo tipo comprende, en cambio, todos los usos lingüísticos que (como en el caso del segundo de los dos sentidos de «interpretación linguiística»y, respectivamente, de «significado ordinario»), no abandonan, aunque sea con alguna reserva, la noción de significado literal sino que la redefinen y/o la remiten a una caracterización más amplia, sincrética y multiforme a un mismo tiempo.

\subsection{Distintas concepciones de «interpretación»}

Si ya la variedad de concepciones del literalismo, conjuntamente con la pluralidad de denominaciones de algunas de ellas, es suficiente para provocar graves perplejidades sobre la noción de interpretación literal, la situación se complica ulteriormente si se toman también en consideración las distintas concepciones que tienen los juristas de la interpretación.

En efecto, se pueden distinguir fácilmente diversas caracterizaciones no equivalentes del proceso interpretativo ${ }^{64}$. De particular importancia, entre

${ }^{63}$ R. S. Summers / G. Marshall [1992, pp. 224-215].

${ }^{64}$ R. Guastini [1990, ${ }^{2} 1992$, pp. 103-107] enumera cinco formas distintas en las que los juristas usan «interpretación»: «(1) In senso stretto, "interpretazione" è impiegato per riferirsi alla attribuzione di significato ad una formulazione normativa in presenza di dubbi o controversie intorno al suo campo di applicazione [...]; (2) in senso lato, "interpretazione" è impiegato per riferirsi a qualsiasi attribuzione di significato ad una formulazione normativa, indipendentemente da dubbi o controversie [...]; (3) In senso molto lato, interpretazione è talvolta impiegato per riferirsi genericamente all»insieme del lavoro dei giuristi, il quale include -ac- 
las diversas distinciones posibles, es la contraposición paradigmática entre dos concepciones fundamentales de la interpretación: (a) la concepción tradicional, aún hoy dominante, según la cual no hay interpretación cuando la formulación lingüística de un texto normativo es suficientemente clara y (b) la concepción heterodoxa según la cual siempre hay interpretación, independientemente de la presunta claridad de la formulación lingüística de un texto normativo. (Alternativamente, sin poner el acento en las formulaciones lingüísticas, sino sobre los casos a los que las normas se aplican, esta oposición paradigmática puede ser reformulada como la oposición entre la concepción según la cual no hay interpretación cuando el caso es suficientemente claro y la concepción según la cual, en cambio, hay siempre interpretación, con independencia del hecho de que el caso sea claro o no.)

El brocardo usualmente asociado a la concepción tradicional es «in claris non fit interpretatio» ${ }^{65}$.

De modo simétrico, acogiendo una propuesta aparentemente provocativa de Irti, se podría afirmar que la máxima idónea para representar la concepción no ortodoxa podría ser: «in obscuris non fit interpretatio»; ${ }^{66} \mathrm{es}$ de-

canto all'interpretazione vera e propria [...]- anche altre operazioni, quali ad esempio: 1'identificazione delle fonti del diritto valide e la cosiddetta "sistemazione" del diritto, o costruzione in sistema delle norme giuridiche [...]; (4) in alcuni contesti "interpretazione" è impiegato per denotare un trattamento dei testi giuridici (percepito come) scorretto, o manipolatorio [...]; (5) infine, occasionalmente, e del tutto inopportunamente, "interpretazione" è talvolta usato come sinonimo di "applicazione"». (El primer y el segundo uso corresponden a las que en el texto han sido identificadas, respectivamente, como concepción tradicional y concepción heterodoxa) Una caracterización ulterior de «interpretación» que no se corresponde con ninguno de los cinco usos del término identificados por Guastini, puede encontrarse en G. Zagrebelsky [1992, p. 182]: «Attività mediana che si colloca sulla linea di tensione che lega la realtà al diritto, ciò che rappresenta l'ennesima riproposizione della lotta mai spenta e forse irrinunciabele tra la ratio del caso e la voluntas della legge». Y también es parcialmente distinta de la propuesta de Guastini la distinción entre tres sentidos de «interpretación» trazada en diversas ocasiones por Wróblewski. Cfr., por ejemplo, J. Wróblewski [1969, ${ }^{2} 1983$, pp. 72-73] y [1992, pp. 87-88]. Finalmente, sin estar circunscrito al ámbito jurídico, M. Ferraris [1988, pp. 136-137] enumera siete usos de «interpretación».

${ }^{65}$ De los muchos trabajos en los que se enuncia explícita o implícitamente (pero de forma patente) la concepción tradicional, cfr., por ejemplo, H. Hart [1961, capítulo VII]; J. Wróblewski [1969, ${ }^{2}$ 1983], [1983], [1992, p. 97]; F. Schauer [1991, pp. 207-212], J. Raz [1996, p. 350], R. S. Summers [1997, p. 107]. La concepción tradicional es también asumida en las diversas contribuciones a N. MacCormick / R.S. Summers (ed.) [1991]. Finalmente, sin estar circunscrita únicamente al ámbito jurídico, una clara afirmación de la concepción tradicional estándar es ofrecida por M. Ferraris [1998, p. 136]: «Solo se si riuscirà a mostrare che ci sono molti casi in cui non si interpreta abbiamo qualche speranza di definire che cosa propriamente sia "interpretare"» (la cursiva es del autor).

${ }^{66}$ Entre los pocos trabajos que explícita o, más fácilmente, implícitamente remiten a la concepción heterodoxa, cfr., por ejemplo, H. Kelsen [1934 a, capítulo VI], [1934b], [1960, capítulo VII]; A. Ross [1958, capítulo IV]; G. Tarello [1974], [1980]; R. Guastini [1990, $\left.{ }^{2} 1992\right]$, [1993]; R.J. Vernengo [1994]. 
cir, es la oscuridad (como, por ejemplo, la autocontradicción o el sin sentido) la que cierra la posibilidad de interpretación, no la claridad. En otras palabras, la formulación de un texto normativo sólo puede considerarse clara en función, y como resultado, de un proceso interpretativo. Así, según Irti:

la chiarezza non è presupposto, ma risultato dell'interpretazione: un testo verbale di per sé $[\ldots]$ non è né chiaro né oscuro, né distinto né confuso. Soltanto il processo interpretativo e la graduale applicazione dei metodi prescritti dal legislatore sono in grado di dirci se il testo è «chiaro» 0 «oscuro» ${ }^{67}$.

La contraposición paradigmática entre la concepción tradicional y la heterodoxa, reviste también (aunque no exclusivamente) un interés particular por sus implicaciones de tipo epistemológico y por sus asunciones de tipo lingüístico.

En particular, bajo un punto de vista epistemológico, el proceso interpretativo adquiere una connotación de carácter cognoscitivo-declarativo, en el caso de la concepción tradicional, mientras que, en el caso de la concepción heterodoxa, en cambio, adquiere una connotación de carácter decisorio-constitutivo ${ }^{68}$.

Estas implicaciones opuestas de naturaleza epistemológica de la concepción tradicional y de la concepción heterodoxa tienen su propio fundamento en, y/o están fuertemente condicionadas por, una oposición simétrica entre dos tesis lingüísticas.

La connotación de carácter cognoscitivo-declarativo de la concepción tradicional de la interpretación tiene su fundamento en la tesis lingüística de que las palabras tienen un significado propio; por tanto, dado que el significado literal es manifiesto, su individualización no requiere (excepto casos excepcionales) interpretación alguna.

En cambio, la connotación de carácter decisorio-constitutivo de la concepción heterodoxa de la interpretación niega que las palabras tengan un significado propio y está fuertemente influenciada por la tesis lingüística que sostiene que el significado de cualquier expresión (con independencia de su aparente claridad) es siempre el resultado de un proceso interpretativo en el que intervienen una pluralidad de variables heterogéneas, lingüísticas y no lingüísticas.

En resumen, la concepción tradicional conlleva una forma de literalismo lingüístico (no necesariamente radical), mientras que la concepción hetero-

${ }^{67}$ N. Irti [1996, pp. 63-66], (la cursiva es del autor). No menos crítico es el comentario formulado por R.J. Vernengo [1994, pp. 19-20, nota 1]: «La ley clara -iclara en qué circunstancias y para quién?- suele resolverse con algún brocado, del tipo in claris non est interpretatio, que tiene la ventaja, por su manifiesta oscuridad, de dejar el problema tal cual».

${ }^{68}$ Sobre la oposición paradigmática cognoscitivo-declarativo $v s$. decisorio-constitutivo cfr., por ejemplo, T. Mazzarese [1992, pp. 294-298] y [1999]. 
doxa conlleva una forma de literalismo lingüístico moderado (aunque no necesariamente una forma de antiliteralismo).

Hasta aquí no se presentan problemas, a no ser que no se preste atención a los resultados que se obtienen de la combinación de los términos de la contraposición paradigmática entre las dos principales concepciones de la interpretación jurídica (la tradicional y la heterodoxa) y las dos principales posiciones sobre el literalismo jurídico (radical y moderado), anteriormente distinguidas en función de la variedad de formas en que los juristas denominan y/o entienden el significado literal.

\section{3. «Interpretación literal»: comentarios a modo de conclusión sobre una expresión dudosa}

El intento de confrontar y combinar las dos principales concepciones de la interpretación con las dos principales posiciones sobre el literalismo jurídico no sólo permite poner de manifiesto la ambigüedad de la locución «interpretación literal», sino también destacar el carácter íntimamente paradójico de cada una de las cuatro nociones que se pueden obtener combinatoriamente.

En particular, dos de los cuatro sentidos combinatoriamente posibles de «interpretación literal» resultan un sinsentido; el tercero resulta, en cambio, autocontradictorio y el cuarto sí parece sensato, pero de carácter más sincrético que no fundado efectivamente en la noción de significado literal.

«Interpretación literal» resulta ser un sinsentido tanto en el caso de la concepción tradicional de la interpretación combinada con la posición del literalismo jurídico moderado, como en el caso de la concepción heterodoxa de la interpretación combinada con la posición del literalismo jurídico radical.

En el primer caso, «interpretación literal» es un sinsentido porque la concepción tradicional de la interpretación está fuertemente condicionada por la tesis lingüística que sostiene que las palabras tienen un significado propio y que esto es (casi) todo cuanto es necesario para individualizar el significado de un enunciado, mientras que, simétricamente, el literalismo jurídico moderado (en abierta oposición con la concepción tradicional de la interpretación) considera la locución «significado literal» como poco más que una etiqueta sincrética para denominar un gran número de criterios interpretativos heterogéneos.

En el segundo caso, «interpretación literal» es un sinsentido porque (en clara oposición con la tesis que caracteriza al literalismo jurídico radical) la concepción heterodoxa de la interpretación está fuertemente condicionada por la tesis lingüística que sostiene que el significado de cualquier expresión lingüística es una función de una pluralidad de variables diferentes, en- 
tre las que el significado literal tiene (en caso de que lo tenga) un papel únicamente subsidiario, mientras que, simétricamente, el literalismo jurídico radical (en clara oposición con la tesis principal de la concepción heterodoxa de la interpretación) considera el significado literal como el elemento central que, según el principio composicional, lleva a la individualización del significado de cualquier expresión lingüística.

Más aún, «interpretación literal» resulta ser una noción autocontradictoria cuando se combina la concepción tradicional de la interpretación con el literalismo jurídico radical. No se comprende, en efecto, qué se entiende por interpretación literal si, según la concepción tradicional de la interpretación, in claris non fit interpretatio; esto es, si la oscuridad se asume como condición necesaria de la interpretación.

Por último, «interpretación literal» es una noción sensata si se combina la concepción heterodoxa de la interpretación con el literalismo jurídico moderado; es decir, cuando interpretación literal no significa más que una interpretación según la cual el significado literal es, quizás, el punto de partida, pero cuyos confines no son necesariamente insuperables ${ }^{69}$.

\section{Interpretación literal y seguridad jurídica}

Las observaciones que preceden conducen a una conclusión descorazonadora: en los casos en que no es autocontradictoria o un sinsentido, la locución «interpretación literal» no identifica ningún criterio preciso, unívocamente determinado, sino que remite, en cambio, a una pluralidad de criterios heterogéneos que varían, según los casos, en relación con distintas lecturas de cada texto normativo.

$\mathrm{Si}$, a pesar de su tenor desagradablemente pesimista, esta conclusión es correcta, resulta inevitable preguntarse por qué los juristas se obstinan en prescribir o, según los casos, recomendar o afirmar que la interpretación debe encontrar su propio fundamento en el significado literal, en el significado propio de las palabras. La razón no es, ciertamente, la falta de actualización de sus conocimientos ni la proverbial resistencia a modificar sus propias categorías conceptuales más tradicionales. La razón por la que los juristas siguen recurriendo a la interpretación literal (con la variedad de de-

${ }^{69}$ Un ejemplo de esta forma de entender la interpretación literal lo ofrece la caracterización que Kelsen realiza de su propia noción de «interpretación auténtica»; es decir, de la interpretación autoritativa realizada por cualquier órgano jurídico en la aplicación del derecho. Según H. Kelsen [1960, p. 352]: «Debe tenerse en cuenta que por vía de interpretación auténtica, es decir, de interpretación de una norma por el órgano jurídico que tiene que aplicarla, no sólo puede llevarse a efecto una de las posibilidades mostradas en la interpretación cognoscitiva de la norma aplicable, sino que también puede producirse una norma que se encuentre enteramente fuera del marco que configura la norma aplicable». La cita se toma de la traducción española: H. Kelsen [1986, pp. 354-355]. 
nominaciones y caracterizaciones propuestas), es, aunque pueda parecer simple y banal, la defensa del valor sumamente celebrado y fuertemente enfatizado de la seguridad jurídica ${ }^{70}$.

Del mismo modo que un buen número de tesis importantes, que se reflejan de formas diversas sobre los presuntos aspectos lógicos y/o racionales de las distintas formas del lenguaje y del razonamiento jurídico, la interpretación literal es considerada como un instrumento necesario para afirmar que la seguridad jurídica puede y debe ser perseguida y asegurada. Temiendo que, de otra forma, el terrorífico caos de la pura arbitrariedad pueda no tener ya obstáculo alguno, a los efectos de defender y afirmar la seguridad jurídica, los juristas siguen apoyándose en la interpretación literal (así como en algunas otras tesis sobre la presunta dimensión lógico-racional del lenguaje y del razonamiento jurídico), indiferentes ante cualquier dificultad, de la que pueden incluso ser conscientes, y desdeñosos de cualquier crítica que sus propias investigaciones pueden haber contribuido magistralmente a poner de manifiesto. En otros términos, los juristas prescriben, recomiendan y defienden la interpretación literal principalmente por su fuerza evocativa y no por su eventual capacidad heurística.

La siguiente pregunta que se impone es, entonces, si la seguridad jurídica merece una defensa tan denodada y tenaz que lleve a los juristas a minusvalorar (si no a ignorar) las dificultades de carácter explicativo que anulan la propia posibilidad de que aquélla sea alcanzada. En otras palabras, la cuestión es si, y en su caso en qué medida, la seguridad jurídica es un valor tan indudablemente deseable como para ser perseguido con independencia de toda consideración sobre la debilidad de los instrumentos explicativos sobre cuya base se fundamenta la posibilidad de que aquél sea alcanzado.

A pesar del amplio consenso del que goza todavía el valor de la seguridad jurídica, la respuesta es más problemática de cuanto pueda creerse.

La seguridad jurídica y/o la interpretación literal como instrumento necesario para garantizar su obtención son, en efecto, el objeto no sólo, a nivel explicativo, de la pluralidad de críticas de naturaleza lingüística de las que se ha hecho mención, sino también, a nivel prescriptivo, de una diversidad de críticas de distinta naturaleza.

Un primer tipo de críticas es de carácter jurídico y concierne al propio funcionamiento del derecho, su eficacia y su eficiencia. En concreto, para evitar el resultado autodestructivo de una ley que difícilmente encuentre aplicación, su formulación lingüística debe ser, al menos en alguna medida, indeterminada. Denominada y/o caracterizada de formas no siempre coin-

${ }^{70}$ Entre las defensas más fuertes y apasionadas de la seguridad como valor constitutivo del derecho no puede evitarse la remisión al ya clásico F. López de Oñate [1942, $\left.{ }^{3} 1968\right]$. 
cidentes, la necesidad de una voluntaria indeterminación en el lenguaje del legislador, es objeto de atención en muchos trabajos ya a partir de 1934, año de publicación de la primera contribución de Kelsen a la teoría de la interpretación $^{71}$.

Un segundo tipo de críticas a la seguridad jurídica, y a su criterio subyacente de la interpretación literal, es de carácter político ${ }^{72}$. En concreto, la cuestión de si el criterio de la presunta interpretación literal debe considerarse el principal instrumento interpretativo (y, en su caso, en qué medida), y si la seguridad debe considerarse como un valor jurídico absoluto, es (o al menos puede ser) un problema de valoración política y, por tanto, de carácter contingente e ideológicamente condicionado. Este punto encuentra una clara (pero, quizás, no intencional) formulación en Bobbio cuando discute acerca de la oposición paradigmática entre interpretación conceptual e interpretación dirigida a los objetivos sociales y a los intereses. Escribe, en efecto, Bobbio:

è probabile che la scelta stessa del metodo sia condizionata dall'apprazzemento favorevole o sfavorevole delle conseguenze della decisione. Il giudice adotterà questo o quel metodo secondo che vorrà conseguire questo o quel risultato. [...] Una volta che sia riconosciuto il valore decisivo del fine, la disputa non è più metodologica, ma ideologica. Si tratta di sapere, se mai, quale delle

${ }^{71}$ Cfr. H. Kelsen [1934 b] y también [1934 a, capítulo VI] y [1960, capítulo VII]. Circunscribiendo la atención a los trabajos publicados después de la contribución de Kelsen en 1934, cfr., además, A. Ross [1958, capítulo IV], H. Hart [1961, capítulo VII], G. Carrió [1965, ${ }^{4} 1990$, pp. 26-36 y pp. 133-168], W. Twining / D. Miers [1976, ${ }^{2} 1982$, capítulo V], M. Moore [1980-1981, pp. 180-202], J. Wróblewski [1983], C. Luzzati [1990], B. Bix [1993], F. Schauer [1993, pp. XIII-XIV], F. Denozza [1995, pp. 28-32], J.J. Moreso [1997 a, pp. 108-125], G.L. Palombella [1997, p. 127].

${ }^{72}$ Una denuncia clara y explícita de la ambivalencia política del requerimiento de la seguridad jurídica, tal y como se expresa en la tensión, en época renacentista, entre emergentes estamentos comerciales y la afirmación del absolutismo de los estados modernos, puede encontrarse en D. Corradini [1971, pp. 12-13]: «gli scopi che le due forze si proponevano di raggiungere, tramite la riduzione a sistema dei precetti giuridici e in specie delle norme privatistiche, divergono profondamente. Da un canto, promuovendo un "modello garantistico" che si sarebbe sviluppato con compiutezza nella dottrina del liberalismo, si sostiene che la legge scritta e valida indistintamente per i cittadini è necessaria perché siano riconosciuti come irrinunciabili i diritti fondamentali della persona e in primo luogo il diritto alla propietà. Dall'altro, in linea con un "modello assolutistico" o "statualistico" che accentua il momento dell'autorità nei rapporti fra gli organi di governo e i consociati, si scorge nella legislazione e nella codificazione il mezzo per sopprimere i particolarismi locali connessi al predominio della consuetudine, e quindi per rendere più saldo il potere sovrano. E proprio in quanto la medesima richiesta di certezza giuridica si lega a contenuti diversi, la riflessione intorno alla figura del giudice, e ai compiti che egli assolve, è destinata a mutare a seconda dell'angolo di visuale prescelto. Anche qui, infatti, le strade sembrano dividersi: o si desiderano stabilire severi limiti all'attività dei tribunali per evitare che le sentenze scalfiscano le prerogative inviolabili $\mathrm{e}$ l'autonomia dell'uomo; oppure si reclama una legislazione armonica per impedire che i magistrati infrangano i comandi imposti dall'alto». 
due ideologie sia da preferirsi. Ma da parte di chi? in quali circostanze? Il dire [...] che l'interpretazione concettuale è più conservatrice e quella rivolta agli scopi sociali e agli interessi è più progressiva, non vuol dire formulare un giudizio di valore: «conservatore» e «progressivo» vengono usati in questo contesto nel loro uso descrittivo, l'uno indicante la funzione di mantenere uno status $q u o$, l'altro quello di mutarlo. Che questa operazione sia da apprezzare o disapprovare dipende unicamente dalla valutazione che diamo allo status quo ${ }^{73}$.

Un tercer tipo de críticas a la seguridad jurídica, y a su criterio subyacente de la interpretación literal, es de carácter ético. En concreto, ya sea por el carácter específicamente pluralista de la sociedad contemporánea, ya sea por el reconocimiento explícito de un gran número de derechos fundamentales por parte de muchos ordenamientos jurídicos contemporáneos, el modelo liberal del estado de derecho se está sustituyendo patentemente por un modelo de ordenamiento jurídico distinto que refleja la variedad de concepciones jurídicas y sociales acerca del modo de entender los valores últimos. Así, según el modelo de «derecho dúctil» propuesto por Zagrebelsky ${ }^{74}$, los efectos negativos que, sobre la seguridad jurídica, conllevan la falta de consenso social y jurídico sobre los valores últimos a defender y a implementar, no están en absoluto en contraste con cuanto requieren los ordenamientos jurídicos modernos, sino que, al contrario, son un resultado obvio del carácter intrínsecamente dinámico de los principios fundamentales que ellos mismos establecen que deben protegerse ${ }^{75}$.

${ }^{73}$ N. Bobbio [1958, ${ }^{2} 1977$, pp. 95-96]. Claramente distinto, en cambio, es el tono de N. Bobbio [1951] cuando, en una feroz recensión a la sexta edición de Law and The Modern Mind de Jerome Frank, afirma que «non si può nemmeno immaginare un ordinamento giuridico senza che sussista una sia pur minima garanzia di certezza» (p. 151), e ancora «Non gli viene il sospetto [...] che la certezza del diritto [...] sia un elemento intrinseco del diritto, sì che il diritto o è certo o non è neppure diritto [...] Non gli passa neppure per la mente che al problema della certezza del diritto siano legati problemi fondamentali per la coesistenza ordinata dell'uomo, come quello della difesa contro l'arbitrio [...] e della protezione dell'eguaglianza giuridica. [...] Non lo agita il minimo dubbio che il problema della certezza del diritto, che corrisponde al bisogno umano di fondare la coesistenza sopra un complesso di regole stabili e non caduche, durature e non provvisorie, sia un problema storico (e non banalmente psicologico)» (pp. 150-151).

${ }^{74}$ Temáticas parecidas a las enunciadas por Zagrebelsky en la elaboración de su modelo de «derecho dúctil», son propias, de forma más general, de la que, en el último decenio, se está imponiendo claramente como una nueva concepción del derecho: el neoconstitucionalismo. Concepción que, aún dentro de su ya rica variedad de formulaciones distintas, se caracteriza por la oposición paradigmática entre estado (liberal) de derecho y estado constitucional de derecho, modelo estatal, este último del que se indagan formas y modos de configuraciones posibles, así como la variedad y pluralidad de implicaciones iuspolíticas a nivel nacional y supranacional.

${ }^{75}$ Escribe G. Zagrebelsky [1992, pp. 200-202]: «Quello che può apparire come l'arbitrio degli interpreti e l'incertezza del diritto non dipendono affatto [...] da una o da un'altra concezione dell'interpretazione del diritto ma da molto più profonde condizioni nelle quali il di- 
Por último, a los efectos de retomar y concluir la ejemplificación de algunos de los diversos tipos de críticas que, a nivel prescriptivo, pueden realizarse al valor de la seguridad jurídica, y a su subyacente y característico criterio de la interpretación literal, pueden mencionarse dos últimos comentarios, tomados de Lombardi Vallauri.

\section{Primero:}

Il valore della certezza del diritto [...] non è il valore unico e supremo. E quindi, quando anche si dimostrasse che una metodologia produce più certezza, resterebbe ancora da dimostrare che essa è per ciò stesso migliore in senso assoluto $^{76}$.

\section{Segundo:}

La vera scorrettezza metodologica dei giudici e dei giuristi in generale non sta tanto nell'opzione per la metodologia «eclettica» dei risultati, quanto nel carattere criptico di questa opzione, che sottrae alla luce della discussione le motivazioni reali ${ }^{77}$.

\section{Referencias bibliográficas}

Aarnio, Aulis [1991], Statutory Interpretation in Finland. En: MacCormick, Neil / Summers, Robert S. (eds.), Interpreting Statutes. A Comparative Study. Aldershot, Dartmouth, pp. 123-170.

Aissen, Judith / Hankamer, Jorge [1977], Ambiguità. En: Enciclopedia Einaudi. Torino, Einaudi, vol. 1, pp. 417-449.

ritto è chiamato a operare. Nello Stato liberale di diritto dell'acutezza di questi problemi non si aveva sentore e l'interpretazione poteva ridursi alla ricerca del significato delle norme volute dal legislatore. [...] La ragione della temuta "esplosione" soggettivistica dell'interpretazione è $[\ldots]$ da rintracciare nel carattere pluralistico della società attuale e di quella società parziale che è la comunità dei giuristi e di coloro che operano attraverso il diritto. [...] La causa dell'incertezza nei processi dell'applicazione del diritto non è in una cattiva disposizione mentale dei giuristi ma nel deperimento di un quadro di principî di senso e valore generalmente condiviso. [...] Se ciò comporta conseguenze negative sulla certezza del diritto, occorre avere chiaro che esse non sono lo stravolgimento, ma la conseguenza dei sistemi giuridici attuali. [...] Se si tiene conto di alcuni dati di fatto: che oggi i principî contenenti valori di giustizia sono divenuti diritto positivo inserito nella costituzione; che quindi l'appello alla giustizia accanto o contro le regole della legge, non può più essere visto come un gesto eversivo e distruttivo del diritto [...] ma è un evento previsto e ammesso; che tali principî consistono essenzialmente in "nozioni a contenuto variabile" e quindi svolgono una funzione essenzialmente dinamica, se si considera tutto questo, si comprenderà allora che una forza permanentemente orientata al mutamento è stata così inserita nell'ordinamento». Para una crítica al modelo de Zagrebelsky y a las implicaciones que éste conlleva respecto de la seguridad jurídica, cfr. R. Guastini [1996].

${ }^{76}$ L. Lombardi Vallauri [1971, ${ }^{2} 1981$, p. 81].

${ }^{77}$ L. Lombardi Vallauri [1971, ${ }^{2} 1981$, p. 83]. 
Alexy, Robert / Dreier, Ralf [1991], Statutory Interpretation in Federal Republic of Germany. En: MacCormick, Neil / Summers, Robert S. (eds.), Interpreting Statutes. A Comparative Study. Aldershot, Dartmouth, pp. 73-121.

Austin, John L. [1962], How To Do Things with Words. Oxford, Clarendon Press.

Bankowski, Zenon / MacCormick, Neil [1991], Statutory Interpretation in the United Kingdom. En: MacCormick, Neil / Summers, Robert S. (eds.), Interpreting Statutes. A Comparative Study. Aldershot, Dartmouth, pp. 359-406.

Belvedere, Andrea [1997], Testi e discorsi nel diritto privato. En: «Ars Interpretandi», 2 (1997), pp. 137-156.

Bix, Brian [1993], Law, Language and Legal Indeterminacy. Oxford, Clarendon Press.

Bobbio, Norberto [1951], La certezza del diritto è un mito? En: «Rivista internazionale di filosofia del diritto», 28 (1951), pp. 146-152.

Bobbio, Norberto [1958, ${ }^{2}$ 1977], Sul formalismo giuridico. En: «Rivista italiana di diritto e procedura penale», 1 (1958), pp. 977-998. Reed. en: Bobbio, Norberto, Giusnaturalismo e formalismo giuridico. Milano, Comunità, pp. 79-100.

Bolinger, Dwight [1989], Intonation and Its Uses. Melody in Grammar Discourse. London, Edward Arnold.

Borutti, Silvana [1983], Significato. Saggio sulla semantica filosofica del '900. Bologna, Zanichelli.

Carcaterra, Gaetano [1994], L'argomento a contrario. En: Cassese, Sabino / Carcaterra, Gaetano / D'Alberti, Marco / Bixio, Andrea (eds.), L'unità del diritto. Massimo Severo Giannini e la teoria giuridica. Bologna, il Mulino, pp. 177272.

Carrió, Genaro [1965, $\left.{ }^{4} 1990\right]$, Notas sobre derecho y lenguaje. Buenos Aires, Abeledo-Perrot.

Chiassoni, Pierluigi [1998], L'ineludibile scetticismo della «scuola genovese». En: Comanducci, Paolo / Guastini, Riccardo (eds.), Analisi e diritto 1998. Torino, Giappichelli, pp. 21-76.

Chiassoni, Pierluigi [1999], La giurisprudenza civile. Metodi di interpretazione e tecniche argomentative. Milano, Giuffrè.

Corradini, Domenico [1971], Garantismo e statualismo. Milano, Giuffrè.

Cruttenden, Alan [1986], Intonation. Cambridge, Cambridge University Press.

Dascal, Marcelo [1981], Contextualism. En: Parret, Herman / Sbisà, Marina / Verschueren, Jef (eds.), Possibilities and Limitations of Pragmatics. Amsterdam, Benjamins, pp. 153-177.

Dascal, Marcelo [1983], Pragmatics and the Philosophy of Mind 1. Tought in Language. Amsterdam, Benjamin.

Dascal, Marcelo [1987], Defending Literal Meaning. En: «Cognitive Science», 11 (1987), pp. 259-281.

Dascal, Marcelo / Wróblewski, Jerzy [1988], Trasparency and Doubt: Understanding and Interpretation in Pragmatics and in Law. En: «Law and Philosophy», 7 (1988), pp. 203-224.

Denozza, Francesco [1995], La struttura dell'interpretazione. En: «Rivista trimestrale di diritto e procedura civile», 49 (1995), pp. 1-73. 
Diciotti, Enrico [1999], Interpretazione della legge e discorso razionale. Torino, Giappichelli.

Eco, Umberto [1984], Semiotica e filosofia del linguaggio. Torino, Einaudi.

Eco, Umberto [1990, $\left.{ }^{2} 1995\right]$, I limiti dell'interpretazione. Milano, Bompiani.

Eco, Umberto [1997], Kant e l'ornitorinco. Milano, Bompiani.

Ferraris, Maurizio [1998], Non ci sono gatti, solo interpretazioni. En: Derridà, Jacques / Vattimo, Gianni (eds.), Diritto, giustizia e interpretazione. Bari, Laterza, pp. 129-163.

Gibbs, Raymond W. [1982], A Critical Examination of the Contribution of Literal Meaning to Understanding Nonliteral Discourse. En: «Text», 2 (1982), pp. 927.

Gibbs, Raymond W. [1984], Literal Meaning and Psychological Theory. En: «Cognitive Science», 8 (1984), pp. 275-304.

Gibbs, Raymond W. [1989], Understanding and Literal Meaning. En: «Cognitive Science», 13 (1989), pp. 243-251.

Guastini, Riccardo [1990, ${ }^{2} 1992$ ], Dalle fonti alle norme. Torino, Giappichelli.

Guastini, Riccardo [1993], Le fonti del diritto e l'interpretazione. Milano, Giuffrè.

Guastini, Riccardo [1996], Diritto mite, diritto incerto. En: «Materiali per una storia de la cultura giuridica», 26 (1996), pp. 513-525.

Haaparanta, Leela [1985], Frege's Doctrine of Being. Helsinki, Acta Philosophica Fennica.

Hart, Herbert [1961], The Concept of Law. Oxford, University Press.

Irti, Natalino [1996], Testo e contesto. Una lettura dell' art. 1362 codice civile. Padova, Cedam.

Jackson, Bernard S. [1999], Significato letterale. Semantica e narrativa nel diritto biblico e nella teoria contemporanea del diritto. En: «Ragion Pratica», 7 (1999), n. 12, pp. 153-177.

Jori, Mario [1995], Definizioni giuridiche e pragmatica. En: Comanducci, Paolo / Guastini, Riccardo (eds.), Analisi e diritto 1995. Torino, Giappichelli, pp. 109144.

Katz, Jerrold J. [1977], Propositional Structure and Illocutionary Force. A Study of the Contribution of Sentence Meaning to Speech Acts. New York, The Harvest Press.

Katz, Jerrold J. [1981], Literal Meaning and Logical Theory. En: «Journal of Philosophy», 78 (1981), pp. 203-234.

Kelsen, Hans [1934 a], Reine Rechtslehre. Einleitung in die rechtswissenschaftliche Problematik. Wien, Deuticke.

Kelsen, Hans [1934 b], Zur Theorie der Interpretation. En: «Internationale Zeitschrift für Theorie des Rechts», 8 (1934), pp. 9-17.

Kelsen, Hans [1960], Reine Rechtslehre. Wien, Deuticke. Trad. cast. de Roberto J. Vernengo: Teoría Pura del Derecho, México, D.F., UNAM, 1986.

Kooij, Jan G. [1971], Ambiguity in Natural Language. Amsterdam, North Holland.

Ladd, D.R. [1980], The Structure of Intonational Meaning. Evidence from English. Bloomington, Indiana University Press. 
Lakoff, George [1973], Hedges: A Study in Meaning Criteria and the Logic of Fuzzy Concepts. En: «Journal of Philosophical Logic», 2 (1973), pp. 458-508.

Lakoff, George [1993], The Contemporary Theory of Metaphor. En: Ortony, Andrew (ed.), Metaphor and Thought. Second Edition. Cambridge, Cambridge University Press, pp. 202-251.

Lombardi Vallauri, Luigi [1971, $\left.{ }^{2} 1981\right]$, Corso di filosofia del diritto. Padova, Cedam.

López de Oñate, Flavio [1942, $\left.{ }^{2} 1950,{ }^{3} 1968\right]$, La certezza del diritto. Roma, Tipografia Consorzio Nazionale, 1942. Segunda edición editada por Guido Astuti: Roma Gismondi, 1950. Nueva edición revisada editada por Guido Astuti: Milano, Giuffrè 1968.

Luzzati [1990], La vaghezza delle norme. Milano, Giuffrè.

Lyons, John [1977], Semantics. Cambridge, Cambridge University Press.

Lyons, John [1981], Language, Meaning and Context. Great Britain, Fontana Paperbacks.

MacCormick, Neil [1978], Legal Reasoning and Legal Theory. Oxford, Clarendon Press.

MacCormick, Neil / Summers, Robert S. (eds.) [1991], Interpreting Statutes. A Comparative Study. Aldershot, Dartmouth.

Marconi, Diego [1995], Filosofia del linguaggio. En: Rossi, Paolo (ed.), La filosofia. I Le Filosofie speciali. Torino, UTET, pp. 365-460.

Mazzarese, Tecla [1990], «Enunciato descrittivo d'una norma». Osservazioni su una nozione imbarazzante. En: Studi in memoria di Giovanni Tarello. Milano, Giuffrè, vol. 2, pp. 253-288.

Mazzarese, Tecla [1992], Dubbi epistemologici sulle nozioni di «quaestio facti» $e$ «quaestio juris». En: «Rivista internazionale di filosofia del diritto», 69 (1992), pp. 294-320.

Mazzarese, Tecla [1996], Legal Language and Translation. Six Main Sorts of Problem. En: Lewandowska-Tomaszczyk, Barbara / Thelen, Marcel (eds.), Translation and Meaning Part 4. Maastricht, UPM, pp. 399-412.

Mazzarese, Tecla [1999], Towards the Semantics of «Constitutive» in Judicial Reasoning. En: «Ratio Juris», 12 (1999), pp. 252-262.

Moore, Michael S. [1980-1981], The Semantics of Judging. En: «Southern California Law Review», 54 (1980-1981), pp. 151-294.

Moreso, José Juan [1997 a], La indeterminación del derecho y la interpretación de la Constitución. Madrid, Centro de Estudios Políticos y Constitucionales.

Moreso, José Juan [1997 b], Significado, interpretación y proposiciones normativas. Apuntes para un debate. Manuscrito.

Ogden G.K. / Richards, I.A. [1923, $\left.{ }^{10} 1960\right]$, The Meaning of Meaning. London, Kegan Paul.

Ortony, Andrew [1993], Metaphor and Thought. Second Edition. Cambridge, Cambridge University Press.

Palombella, Gianluigi [1997], La conoscenza nell' interpretazione. Un modello per la giurisdizione. En: «Democrazia e diritto», 37 (1997/2), pp. 125-183. 
Peczenik, Aleksander / Bergholz, Gunnar [1991], Statutory Interpretation in Sweden. En: MacCormick, Neil / Summers, Robert S. (eds.), Interpreting Statutes. A Comparative Study. Aldershot, Dartmouth, pp. 311-358.

Pike, Kenneth L. [194 5], The Intonation of American English. Ann Arbor, University of Michigan Press.

Prandi, Michele [1994], Meaning and Indexicality in Communication. En: Parret, Herman (ed.), Pretending to Communicate. Berlin, Walter de Gruyter, pp. 17-32.

Raz, Joseph [1996], Why Interpret? En: «Ratio Juris», 9 (1996), pp. 349-363.

Rosenfeld, Michel [1990], Deconstruction and Legal Interpretation: Conflict, Indeterminacy and the Temptations of the New Legal Formalism. En: «Cardozo Law Review», 11 (1990), pp. 1211-1267.

Ross, Alf [1958], On Law and Justice. London, Stevens.

Rumelhart, David E. [1979, ${ }^{2}$ 1993], Some Problems with the Notion of Literal Meanings. En: Ortony, Andrew (ed.), Metaphor and Thought. Second Edition. Cambridge, Cambridge University Press, pp. 71-82.

Sadock, Jerrold R. [1979, ${ }^{2}$ 1993], Figurative Speech and Linguistics. En: Ortony, Andrew (ed.), Metaphor and Thought. Second Edition. Cambridge, Cambridge University Press, pp. 42-57.

Schauer, Frederick [1991], Playing by the Rules. A Philosophical Examination of Rule-Based Decision-Making in Law and Life. Oxford, Oxford University Press.

Schauer, Frederick [1993], Introduction. En: Schauer, Frederick (ed.), Law and Language. Aldershot, Dartmauth, pp. XI-XVI.

Searle, John R. [1969], Speech Acts. London, Cambridge University Press.

Searle, John R. [1978, $\left.{ }^{2} 1979\right]$, Literal Meaning. En: «Erkenntnis», 13 (1978), pp. 207-224. Reed. en: Searle, John R., Expression and Meaning. Cambridge, Cambridge University Press, pp. 117-136.

Searle, John R. [1979, ${ }^{2}$ 1993], Metaphor. En: Ortony, Andrew (ed.), Metaphor and Thought. Second Edition. Cambridge, Cambridge University Press, pp. 83-111.

Searle, John R. [1980], The Background of Meaning. En: Searle, John R. / Kiefer, Ferenc / Bierwish (eds.), Speech Acts Theory and Pragmatics. Dordrecht, D. Reidel, pp. 221-232.

Segre, Cesare [1986], Co-text and Context. En: Sebeok, Thomas A. (ed.), Encyclopaedic Dictionary of Semiotics. Berlin, Mouton, vol. 1, pp. 151-152.

Sinclair, Ian [1973, ${ }^{2}$ 1984], The Vienna Convention on the Law of Treaties. Second Edition. Manchester, Manchester University Press.

Summers, Robert S. [1997], Sobre la interpretación legislativa ideal. En: «Isonomía», 6 (1997), pp. 107-130.

Summers, Robert S. / Marshall, Geoffrey [1992], The Argument from Ordinary Meaning in Statutory Interpretation. En: «Ireland Legal Quarterly», 43 (1992), pp. 213-236.

Tarello, Giovanni [1965], Osservazioni sull' individuazione dei precetti. La semantica del neustico. En: «Rivista trimestrale di diritto e procedura civile», 19 (1965), pp. 405-435.

Tarello, Giovanni [1974], Diritto, enunciati, usi. Bologna, il Mulino. 
Tarello, Giovanni [1980], L'interpretazione della legge. Milano, Giuffrè.

Taylor, John R. [1989, ${ }^{2}$ 1995], Linguistic Categorization. Prototypes in Linguistic Theory. Second Edition. Oxford, Clarendon Press.

Troper, Michel / Grzegorczyk, Christophe / Gardies, Jean-Louis [1991], Statutory Interpretation in France. En: MacCormick, Neil / Summers, Robert S. (eds.), Interpreting Statutes. A Comparative Study. Aldershot, Dartmouth, pp. 171-212.

Twining, William / Miers, David [1976, ${ }^{2}$ 1982], How to Do Things with Rules. London, Weidenfeld and Nicolson.

Usberti, Giulio [1995], Significato e conoscenza. Milano, Guerini scientifica.

Van Noppen, J.P. / Hols, E. (eds.) [1990], Metaphor II. A Classified Bibliography of Publications from 1985-1990. Philadelphia, Benjamin.

Vernengo, Roberto [1994], La interpretación literal de la ley. Segunda edición ampliada. Buenos Aires, Abeledo-Perrot.

Viola, Francesco [1997], Intenzione e discorso giuridico: un confronto tra la pragmatica linguistica e l' ermeneutica. En: «Ars Interpretandi», 2 (1997), pp. 53-73.

Waismann, Friedrich [1945, $\left.{ }^{2} 1951\right]$, Verifiability. En: «Proceedings of the Aristotelian Society», supl. vol. XIX, 19 (1945), pp. 101-164. Reed. en: Flew, Antony (ed.), Essays on Logic and Language. Oxford, Basel Blackwell, pp. 117-144.

Williams, Glenn [1945, $\left.{ }^{11} 1982\right]$, Learning the Law. London, Stevens and Sons.

Williamson, Timothy [1994], Vagueness. London, Routledge.

Wróblewski, Jerzy [1969, ${ }^{2}$ 1983], Legal Reasoning in Legal Interpretation. En: «Logique et Analyse», 12 (1969), pp. 3-31. Reed. en: Wróblewski, Jerzy, Meaning and Truth in Judicial Decision. Helsinki, A-Tieto Oy, pp. 71-103.

Wróblewski, Jerzy [1983], Fuzziness of Legal System. En: Kangas, Urpo (ed.), Essays in Legal Theory in Honor of Kaarle Makkonen. Monographic issue of «Oikeustiede», 16 (1983), pp. 311-330.

Wróblewski, Jerzy [1992], The Judicial Application of Law. Editado por Zenon Bankowski y Neil MacCormick. Dordrecht, D. Reidel.

Zagrebelsky, Gustavo [1992], Il diritto mite. Legge diritti giustizia. Torino, Einaudi. Zuleta-Pucerio, Enrique [1991], Statutory Interpretation in Argentina. En: MacCormick, Neil / Summers, Robert S. (eds.), Interpreting Statutes. A Comparative Study. Aldershot, Dartmouth, pp. 29-71.

(Trad. de Jordi Ferrer Beltrán) 


\section{DOXA 23 (2000)}

